\title{
UN TRATADO DE NOBLEZA MANUSCRITO DE UN REGIDOR CORUÑÉS DE PRINCIPIOS DEL SIGLO XVII*
}

\author{
MANUEL-REYES GARCÍA HURTADO \\ Universidad de A Coruña**
}

\begin{abstract}
Resumen
Presentamos la publicación y el estudio anotado de un tratado de nobleza redactado hacia 1621 por el regidor de A Coruña Juan Melio de Sande. Hacemos hincapié en las características comunes a este tipo de textos e intentamos dilucidar las motivaciones de su autor. En su formato, argumentación y autoridades empleadas no hace sino seguir a los más reputados especialistas en materia nobiliaria de su tiempo.
\end{abstract}

\section{Palabras clave}

Nobleza, Hidalguía, Séneca, A Coruña.

\begin{abstract}
We present the publication and annotated study of a treatise on nobility written about 1621 by Juan Melio de Sande, an councillor from A Coruña. We emphasise the characteristics common to these kinds of texts and we try to clarify the author's motives. In his format, argument, and authorities referred to, he could only follow the most reputable specialists on the subject of genealogy at that time.
\end{abstract}

\section{Key Words}

Nobility, «Hidalguia», Seneca, A Coruña.

* Entregado el 15 de marzo de 2005.

** Trabajo financiado con el Proyecto de Investigación «La cultura letrada en el Noroeste Peninsular en la Edad Moderna: De lo oral a lo escrito». Ministerio de Ciencia y Tecnología, BH2001-3310. 


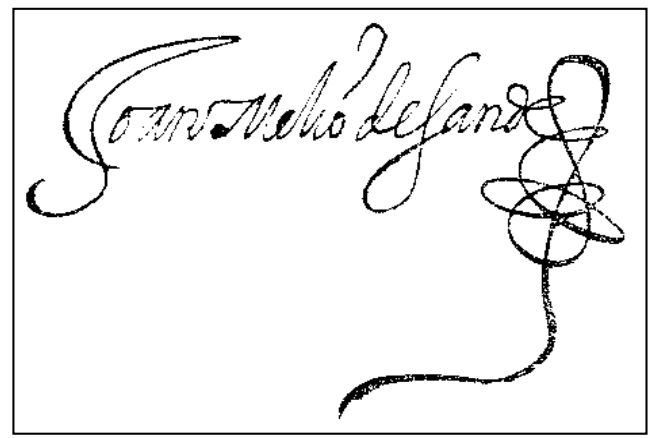

Archivo Histórico Municipal de A Coruña, Libros de Acuerdos Municipales, C-14, fol. 31 r.

En 1621 un regidor de la ciudad de A Coruña llamado Juan Melio de Sande hace llegar al licenciado Pedro Labora de Andrade, a la sazón también regidor en la misma ciudad, un manuscrito en el que relataba el pasado de A Coruña. El texto, que ya analizamos en otro lugar ${ }^{1}$, entra de lleno en el género corográfico y pasa por ser uno de los primeros de este tipo dedicado a una población gallega. Del autor se conservan escasas noticias.

Estimamos que nació en la ciudad herculina hacia 1576 y tenemos referencias que señalan que realizó estudios con los franciscanos. Hay un vacío de datos hasta que lo encontramos como secretario del III Duque de Alcalá en Madrid a principios de la segunda década del siglo XVII, y poco después lo hallamos de nuevo en su ciudad natal como regidor entre los años 1615 y $1625^{2}$. A pesar de que la oscuridad o el desinterés ha ocultado su figura, y esta ha pasado desapercibida o ha merecido simplemente por los cronistas coruñeses menciones brevísimas que se limitaban a dar constancia de su existencia, Melio jugó un papel de primera magnitud en la esfera de las letras a raíz de su publicación de las epístolas morales de Séneca en 1612. Algo que a primera vista parece que se escaparía de su competencia intelectual es fácilmente explicable tanto por el círculo cultural del que pudo participar por su cercanía al Duque de Alcalá, como porque el texto que imprime con su nombre no es más que una readaptación de una traducción anónima del $\mathrm{XV}^{3}$.

Pero Melio no merece un lugar en la memoria histórica sólo por lo ya indicado, sino por algo más. A continuación del relato de las vicisitudes de la ciudad de A Coruña nuestro autor insertó un tratado de nobleza, como él mismo lo denomina, aunque ciertamente el título promete más de lo que ofrece ${ }^{4}$. En suma sigue la estructura de otras obras que tenían por objeto esta misma materia5: origen de la

\footnotetext{
${ }^{1}$ García Hurtado, Manuel-Reyes, «Juan Melio de Sande y sus inquietudes intelectuales: Séneca, la historia de A Coruña y la nobleza», en Rey Castelao, Ofelia (Coord.), Cuatro Textos. Cuatro Contextos. Ensayos de Historia Cultural de Galicia, Santiago de Compostela 2004, 203-82.

${ }^{2}$ Sobre la biografía de Melio ídem, 205-8.

${ }^{3}$ Ídem, 212-13.

${ }^{4}$ Relación de la antigüedad, origen y fundación de la muy noble y muy leal ciudad de La Coruña, cabeza y llave del Ilustrísimo Reino de Galicia. Con un tratado general de Nobleza (1621), $45 \mathrm{hs}$. 19’5 cm. [Madrid, Biblioteca Nacional, Ms. 10734 (h. 117 r.-161 r.), Micro 10054]

${ }^{5}$ GuILLÉn BerRendero, José Antonio, «La tratadística nobiliaria como espejo de nobles. El ejem-
} 
nobleza, definición, fundamentos, vías de adquisición, estimación, virtudes que la caracterizan, jerarquía (con gran atención a la hidalguía ${ }^{6}$ ), armas e insignias ${ }^{7}$, etc. Como él mismo confiesa, y hemos verificado incluso cuando él no lo declara, sus palabras no son más que el reflejo de lo que otros muchos escribieron y debatieron sobre una cuestión de gran actualidad en la España de su tiempo. Ahora bien, que enumere autores no demuestra que conociera sus obras y las leyera de primera mano, y en algunos casos hasta resultaría incomprensible esta circunstancia, puesto que en varias ocasiones yerra en las citas o presenta como apoyo de sus palabras autoridades que si hubiera tenido delante el libro hubiera observado que defendían lo opuesto a lo que él señalaba ${ }^{8}$. Y siguiendo con el capítulo de lo censurable también da muestras de lagunas en su conocimiento de la historia9 9

No estamos ante una obra de carácter jurídico, puesto que adolece de relieve, es muy plana y a veces simplemente descriptiva. Carece de profundidad y de altura teórica. Evidentemente era difícil superar todas estas carencias por un autor que si bien pudo acceder a libros que trataban la cuestión nobiliaria, e incluso sirvió durante su juventud a uno de los más importantes nobles de su tiempo, era ésta una materia que por transitada y debatida, lo cual dista mucho de significar delimitada o clarificada, exigía unos conocimientos jurídicos e históricos que Melio no poseía. Otro muy distinto sería el tono en ese caso. Y no podemos argüir como excu-

plo de Juan Benito Guardiola y su Tratado de Nobleza de 1591», Brocar. Cuadernos de Investigación Histórica, 26 (2002), 90-6; Ídem, «Notas para el estudio de la tratadística nobiliaria en Andalucía. El nobiliario de Gonzalo Argote de Molina», Actas del III Congreso de Historia de Andalucía, Córdoba 2002, 431 y 435.

${ }^{6}$ Sobre su significado en las fechas que escribe Melio ver Covarrubias Orozco, Sebastián de (1539-1613), Tesoro de la Lengua Castellana o Española según la impresión de 1611, con las adiciones de Benito Remigio Noydens publicadas en la de 1674, Ed. preparada por Martín de Riquer, Barcelona 1943, 590-92. Sobre la etimología de esta voz ver FERNÁNDEZ DE EsCALANTE, Manuel Francisco, Hidalgos y fulanos. Dos significados discutidos correspondientes a dos virtualidades espirituales con repercusión jurídica (Más una conexión de sentido sobre actual vasco Jaun), Córdoba 1985, 81 p.; SÁNCHEZ DE AgÜEROS Y DE LA TORRE, Ángel, «La institución «Hidalguía». Su denominación y su origen», Hidalguía, Año XLIII, 250-251 (Mayo-Agosto 1995), 417-42. Escalante defiende una etimología germánica. Subrayamos cómo desde la admisión primigenia de un origen en la palabra fiel, que es la que enuncia en primer lugar Covarrubias, se pasa a la tradicional de hijo y algo que es la que él desarrolla, hasta que actualmente los estudios lingüísticos han rescatado la primitiva etimología.

${ }^{7}$ Destaca el gran espacio que dedica a los diferentes títulos y a los emblemas y símbolos, manifestaciones todos ellos de la expresión pública del honor que se disfruta. MARAVALL, José Antonio, Poder, honor y élites en el siglo XVII 3 ed., Madrid 1989, 75.

${ }^{8}$ Por ejemplo, defiende la riqueza como vía de acceso a la nobleza con citas inexactas o sacadas de contexto de Dante y de Flavio Josefo.

${ }^{9}$ Esto se evidencia al presentar como familiares a personajes que sólo lo eran desde el punto de vista jurídico, pero no de sangre, cuando está intentando enumerar casos en que la sangre actúa como motor de la emulación de la nobleza de los antepasados. 
sa la brevedad de su tratado, ya que no es la razón una cuestión de número de páginas, como muy bien demuestra el precioso texto de Osorio publicado en latín en $1542^{10}$.

¿Qué motivos pudo tener Melio para redactar su tratado? No creemos que puedan ser de tipo personal, es decir, cimentar de una manera colateral sus aspiraciones de ennoblecimiento. La única prueba en esta línea sería su afirmación de los honores de que disfrutó la familia de los Melios en la Roma clásica, pero es harto débil esta defensa para una pretensión nobiliaria, y así se consideraba en su propia época ${ }^{11}$. Sí que podríamos pensar en un interés de Melio, pero no a título individual, sino envuelto en el del grupo social con el que comparte el poder local, y merecedor de ese reconocimiento como valedor de la convivencia y dedicado al bienestar de la población, maniobra en la que no sería innovador ${ }^{12}$. Esto justificaría que estas páginas acompañen a su descripción de la ciudad de A Coruña, texto fruto de un encargo municipal, en la que sin ambages persigue colocar a su patria local en un lugar de privilegio en el conjunto de Galicia. La consecuencia directa del encumbramiento de su ciudad sería el de su elite dirigente ${ }^{13}$, y es un lugar común presentar a los regidores como los auténticos nobles ${ }^{14}$. En este caso encontraríamos así explicación a algunas de las ideas que defiende, como que la riqueza o la ciencia son vías de acceso a la nobleza, algo sobre lo que debatían abiertamente los especialistas ${ }^{15}$, y que permitiría a las clases rectoras de la urbe penetrar en la ansiada cúspide social. Entroncaría pues con aquellos escritores que pretenden establecer una abierta correlación entre nobleza y desempeño de cargos públicos ${ }^{16}:$ :Se

\footnotetext{
${ }^{10}$ Se publicó en castellano a mediados del siglo XX. «La nobleza civil. Por Jerónimo Osorio de Fonseca y Govea. Título original: Hieronymi Osorii Lusitani, Silvensis Episcopi, De Nobilitate Civili, Libri Duo. Traducción: Ángel Sánchez de Agüeros y la Torre», Hidalguía, Año V, 21 (Marzo-Abril 1957), 161-76; Año V, 25 (Noviembre-Diciembre 1957), 805-12; Año VI, 27 (Marzo-Abril 1958), 161-76; Año VI, 31 (Noviembre-Diciembre 1958), 973-84.

11 «Los Julios, los Favios, los Metelos, los Escipiones, yacen enterrados en la misma tumba que la fortuna cavó para el pueblo romano. Si hoy hubiera alguien que pretendiese haber nacido de aquellos sería tan burlado como si defendiese la verdad del sueño de Pitágoras». «La nobleza civil», Año VI, 27 (Marzo-Abril 1958), 172.

12 «La nobleza civil», Año V, 21 (Marzo-Abril 1957), 164-65.

13 «De haber en ella [la ciudad] alguien en quien concurran las virtudes de una Nobleza descollante, fácilmente podría levantar a su Patria de aquella postración y llevarla hasta la dignidad que su propia luz iluminaría. Por ello, no puede concederse que en una ciudad vulgar existan familias ilustres. Así pues, el principal favor de la naturaleza es el haber nacido y haber sido educado en una Patria ilustre. Y después, el haber nacido hijo de progenitores esclarecidos». «La nobleza civil», 173.

${ }^{14}$ RuIz IBÁÑEZ, José Javier, Las dos caras de Jano. Monarquía, ciudad e individuo. Murcia, 15881648, Murcia 1995, 159.

${ }^{15}$ Quintanilla Raso, M. ${ }^{a}$ Concepción, «La Nobleza», en Nieto Soria, José Manuel (Dir.), Orígenes de la monarquía hispánica. Propaganda y legitimación (ca. 1400-1520), Madrid 1999, 68-70.
} 
percibe claramente lo mal que resulta el destino de aquellas ciudades que prefieren ser gobernadas por hombres vulgares». ${ }^{17}$ Serían estas páginas las que suplirían la ausencia de una genealogía de las principales familias coruñesas en su corografía, de difícil redacción ante la inexistencia de gran nobleza en la ciudad, y que dificultaba su labor de consagración de la clase dirigente ${ }^{18}$. Nada de extraño habría en esto, puesto que los tratados nobiliarios suelen tener una función legitimadora. Además, muchos trabajos de este tipo tienen como autores a «oligarcas locales, miembros de los patriciados urbanos que rigen los destinos de las ciudades hispanas» ${ }^{19}$. Tampoco es desdeñable una aspiración ya de ámbito más global relativa a la naturaleza nobiliaria de la población gallega, en la línea de lo argüido años antes por Poza con relación a los vascos ${ }^{20}$ ¿ ¿Es posible que comenzara esta obra siendo criado del Duque de Alcalá y que lo que en un principio iba a tener una mayor extensión y profundidad se quedara en un simple esbozo? En apoyo de esto iría que muchos trabajos de este tenor fueron escritos por sirvientes de nobles ${ }^{21}$. Si bien, nos inclinamos más por un simple ejercicio literario en el que a la par que daba muestras de sus conocimientos variados sobre una temática muy en boga en aquellas fechas, persigue simple y llanamente elaborar un compendio, un breve resumen, de lo que un noble debía saber sobre su condición y dar algo de luz al sombrío panorama general sobre su estatus, motivo este que movió a coger la pluma a otros autores.

Que sea 1621 cuando este manuscrito toma forma puede ser casual, aunque no lo creemos así, al menos no en el caso de la descripción de la ciudad, puesto que coincide con el inicio del reinado de Felipe IV, momento que sin duda alguna el municipio va a aprovechar en su intento de afirmación. Pero tampoco es de desdeñar que en esa fecha se inicia el período en que el Conde-Duque de Olivares tomó las riendas de la política nacional, uno de cuyos pilares será el ataque a la aristocracia, hasta el punto de que en esa fecha se inicia un período complicado para la grandeza de España ${ }^{22}$, aunque recordamos que en A Coruña era inexisten-

\footnotetext{
${ }^{16}$ Domínguez Ortiz, Antonio, Las clases privilegiadas en la España del Antiguo Régimen 3 ed., Madrid 1985, 189-90.

17 «a nobleza civil», Año VI, 27 (Marzo-Abril 1958), 169.

18 «La genealogía sirve también como instrumento de dominación de la elite gobernante, es un arma ideológica de control social». SORIA MESA, Enrique, La Biblioteca genealógica de don Luis de Salazar y Castro, Córdoba 1997, 23.

${ }^{19}$ Ibid., 28.

${ }^{20}$ Poza, Andrés de (†1595), Fuero de hidalguía. Ad Pragmaticas de Toro \& Tordesillas, ed. de Carmen Muñoz de Bustillo, trad. de M. a de los Ángeles Durán Ramas, Bilbao 1997, LI-283 p.

${ }^{21}$ Una muestra de esta realidad en SORIA, La Biblioteca.

22 MARAÑón, Gregorio (1887-1960), El Conde-Duque de Olivares (La pasión de mandar) 3 ed.,
} 


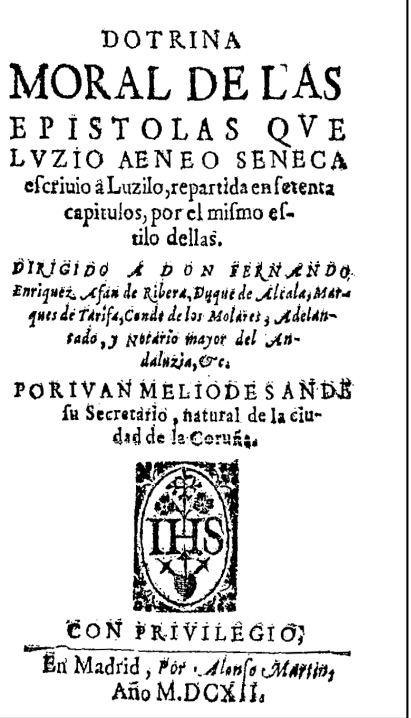

te ${ }^{23}$, de modo que no precisaba elaborar escritos de defensa, ni sería comprensible que ésta fuera tan inmediata. Aunque sea simple coincidencia en este caso, también ese mismo año aparece el que pasa por ser uno de los últimos tratados nobiliarios surgidos a la sombra del debate del siglo precedente: Discursos de la nobleza de España, de Bernabé Moreno de Vargas. Y debió conocerlo puesto que coincide con él en aspectos novedosos, como la afirmación de que el rey no sólo otorga los privilegios de la nobleza, como defendían autores del renombre de Otálora ${ }^{24}$, sino que también era fundador de nobleza ${ }^{25}$.

Las características formales del tratado de Melio son las usuales en la época en este tipo de escritos. Así encontramos gran profusión de citas de autores clásicos (mención especial merece Aristóteles), de la Biblia, de las Partidas y de tratadistas nobiliarios ${ }^{26}$ (Tiraqueau, Clicthove, Cassanaeus, Bartolo de

Madrid 1952, 91-100; JAGO, Charles, «La «crisis de la aristocracia» en la Castilla del siglo XVII», en Elliott, John H. (Ed.), Poder y sociedad en la España de los Austrias, trad. de Xavier Gil Pujol, Barcelona 1982, 248-86.

${ }^{23}$ En consonancia con la debilidad de este grupo en el conjunto de Galicia. VILlares PaZ, Ramón, «La nobleza gallega en los siglos XVI al XIX: La hegemonía de la hidalguía de pazo», en IGLESIAS, Carmen (Dir.), Nobleza y Sociedad III. Las noblezas españolas, reinos y señoríos en la Edad Moderna, Oviedo 1999, 29-62.

${ }^{24}$ Aunque no aparece citado entre los autores que maneja en su tratado, sabemos que conocía su estudio sobre la nobleza, pues lo emplea en su descripción de A Coruña. ARCE DE OTÁLORA, Juan de (h. 1510-1561), De nobilitatis \& inmunitatis Hispaniae, Apud inclytam Granatam, Xantus et Sebastianus Nebrissensis, 1553, [14]-132 h. in-fol. Se reeditó en 1559, 1570 y 1613, con algunos cambios en el contenido y en el título. Sobre este autor SÁNCHEZ DE AGÜEROS Y DE LA TORRE, Ángel, «La autenticidad de la Hidalguía. Un estudio sobre un Tratado», Hidalguía, Año IV, 19 (Noviembre-Diciembre 1956), 731-36; LoRCA MARTín DE VILLODRes, María Isabel, La nobleza en los comienzos del Estado Moderno. El pensamiento del jurista Juan Arce de Otálora, situado en la encrucijada del Medievo y la Modernidad, Madrid 2004, 78 p. Tiene su origen en su tesis doctoral «Las Transformaciones de la Sociedad en los comienzos del Estado Moderno en torno al pensamiento del jurista Juan Arce de Otálora», leída y defendida el 28 de junio de 1996 en la Facultad de Derecho de la Universidad de Málaga, realizada bajo la dirección de Ángel Sánchez de Agüeros y de la Torre.

${ }^{25}$ Sicroff, Albert A., Los estatutos de limpieza de sangre. Controversias entre los siglos XV y XVII, trad. de Mauro Armiño, Madrid 1985, 342-3.

${ }^{26} \mathrm{Y}$ lo mismo acontece en los tratados nobiliarios extranjeros. Para el caso de Portugal resulta interesante y esclarecedor Hespanha, António Manuel, «A Nobreza nos Tratados Jurídicos dos Séculos XVI a XVIII», Penélope. Fazer e Desfazer a História, 12 (1993), 27-42. 
Sassoferrato, Osorio, Guardiola). Otro lugar común es la contraposición entre la nobleza de linaje o de sangre y la de mérito y virtud. Lo cierto es que, a pesar de lo que a priori pudiera pensarse sobre la imposibilidad de acercamiento entre ambas posturas, lo usual será la mezcla de ambas en los textos, la indefinición o simplemente la contradicción. Pensemos que un defensor a ultranza de la nobleza de sangre como Otálora, es al mismo tiempo un acérrimo portavoz de la virtud como «cualidad inescindible de la hidalguía» ${ }^{27}$. Por lo que respecta a Melio, él presenta ambas vías como legítimas, aunque de sus palabras se extrae una abierta predilección por la nobleza de linaje, que entronca con las teorías sobre la limpieza de sangre. Aquí, como en otros puntos, sigue de manera estricta las opiniones de Guardiola $^{28}$, ya que en ambos encontramos que linaje y sangre, detentadores de honor y virtud, son complementados con las riquezas. El camino para alcanzar la nobleza a través del mérito o, lo que es lo mismo, de las buenas obras, de la virtud, se abre paso merced a la moral cristiana y triunfa en la literatura bajomedieval y de los inicios de la Edad Moderna. Ejemplos de esto último los tenemos en algunas de las principales obras maestras de la cultura española ${ }^{29}$, como La Celestina o el Quijote: «Las obras hacen linaje, que al fin todos somos hijos de Adán y Eva. Procure de ser cada uno bueno por sí y no vaya a buscar en la nobleza de sus pasados la virtud ${ }^{30}$; «la verdadera nobleza consiste en la virtud» ${ }^{31}$; «las virtudes adoban la sangre» 32 .

Las páginas que siguen son las últimas conocidas que Melio nos ha legado. Para ser un personaje todavía en espera de autor, él lo fue de una traducción de Séneca, de una descripción de A Coruña y de un tratado de nobleza. ¿Cómo explicar que un individuo de una formación intelectual más que cuestionable sea autor de tres textos para los que se requería, en principio, un profundo dominio del latín en el primer caso, de la historia en el segundo y de la jurisprudencia en el tercero? Pues sencillamente porque contó con los mimbres precisos para redactarlos, más que nada merced a los empleos que desempeñó y cargos que ostentó, ya que como secretario del III Duque de Alcalá logró ubicarse en las proximidades de los círculos intelectuales de la Corte y tener acceso a manuscritos e impresos que de otro modo

27 LORCA, La nobleza, 76.

${ }^{28}$ GUILLÉN, «La tratadística nobiliaria», 101.

29 García Valdecasas, Alfonso, El hidalgo y el honor 2 ed., Madrid 1958, IX p.-3 h.-215 p. Incluye abundantes citas de obras y autores españoles del Siglo de Oro.

${ }^{30}$ Rojas, Fernando de (1470-1541), La Celestina, ed. de Federico Carlos Sainz de Robles, Madrid 1988, Acto Noveno, 218.

${ }^{31}$ Cervantes SaAvedra, Miguel de (1547-1616), Don Quijote de la Mancha 13 ed., Texto y notas de Martín de Riquer, Barcelona 1995, Parte I, cap. XXXVI, 376.

32 Ídem, Parte II, cap. XXXII, 777. 
hubieran permanecido ignorados para él, y como regidor de la ciudad de A Coruña los documentos conservados en el ayuntamiento tuvieron gran parte en su historia de la ciudad herculina. Melio no es un creador, un pensador, sino un divulgador, un lector y transmisor de las ideas de otros que presenta con un lenguaje directo, nada elaborado, ausente de citas en latín, y que en breves páginas consigue exponer su concepción del grupo hacia el que todo español de la época sentía la mayor veneración, y cuyos valores centrales de honor, honra y sangre, inundan al conjunto de la sociedad. Y su ciudad natal no quedó al margen de esta pulsión general, como él testimonia con el texto que presentamos.

\section{(h. 139) ${ }^{33}$ Tratado de Nobleza}

\section{Capítulo I. De su origen y cómo siempre la hubo}

Fundan los doctores haber tres maneras de nobleza ${ }^{34}$ : teologal, natural ${ }^{35}$ y política. Teologal es la que alcanzan los santos, la cual propiamente se dirá santidad. La natural es la que participa de más utilidad, hermosura y valor que otra por naturaleza. La política la que viene por sangre clara y antigua de los padres, continuándose la sucesión en los descendientes, la cual tomó origen de la virtud, y si al principio en todos se conservara no se tratara de nobleza, pero necesario es que la virtud se conozca por el vicio y la nobleza por la vileza. Noé y su familia engendrados fueron de una materia, de una sustancia, y de un mantenimiento gobernados, ¿pues quién a los que procedieron de ellos diferenció en el honor y prerrogativa? La virtud. Cosa cierta es mostrarse los hombres claros e ilustres cuando con obras valerosas e insignes se levantan y diferencian de la vulgar gente, y es llano que de los / hechos heroicos y de las señaladas virtudes depende la nobleza, porque de otra manera quedara sepultada y en tinieblas. La división de los malos y de los buenos se manifestó en los primeros hijos de nuestros primeros padres ${ }^{36}$. Lo mismo en los

\footnotetext{
${ }^{33}$ Hemos modernizado la ortografía y los signos de puntuación. Siempre indicamos el número de la hoja del manuscrito que estamos transcribiendo empleando (h. número) cuando es el recto de la hoja y el símbolo / para señalar que se inicia el verso.

${ }^{34}$ Esta diferenciación es de origen medieval. QuintANILLA, «La Nobleza», 67.

${ }^{35} \mathrm{La}$ natural se divide en dos, relativa la primera a las virtudes naturales (por tanto afecta a todo lo creado) y la segunda se denomina moral (se circunscribe a los hombres). Ver MoRENO DE VARGAS, Bernabé (Regidor de Mérida, 1576-1648), Discvrsos de la Nobleza de España, En Madrid, Por la Biuda de Alonso Martin, 1622, h. 3 r.-vto., 6 vto.-7 r.

${ }^{36}$ Referencia explícita a Caín y Abel (Génesis, 4, 1-12).
} 
de Noé, que visitando por su persona mucha parte del mundo castigó a los malos y premió a los buenos, que por su esfuerzo y virtud alcanzaron reputación y preeminencias, de que se siguió hacerse más claros y nobles que los otros que se abatieron y mostraron de poco ánimo y poca virtud ${ }^{37}$. Que siempre haya habido esta nobleza consta del Deuteronomio, capítulo $1^{38}$, y que escogió Moisés jueces nobles para el pueblo de Israel ${ }^{39}$ lo declara el Libro de los Reyes, capítulo 9, tratando de la elección del rey Saúl y de Samuel ${ }^{40}$, y Jeremías, capítulo 39, refiere que el rey de Babilonia mató a todos los nobles de Judá ${ }^{41}$. David canta en el salmo 149 para hacer vergüenza a las gentes y castigar a los reyes en cadenas y a los nobles en prisiones de hierro ${ }^{42}$. San Pablo dice que convirtió a la fe del Señor con su predica-

${ }^{37}$ Arrepentido Dios de haber creado al hombre determina su exterminio (Génesis, 6), pero Noé y sus hijos Sem, Cam y Japhet, junto a sus esposas y parejas de todas las especies animales, sobreviven al diluvio tras recibir la orden de construir un arca. Pero también entre sus hijos hubo quien no estuvo a la altura de las circunstancias (Génesis, 9, 18-27) y recibió la condena del propio Noé.

38 Deuteronomio 1, 13-15: «"Elegid de vuestras tribus hombres sabios, inteligentes, probados, para que yo los constituya sobre vosotros". Y vosotros me respondisteis: "Está bien lo que nos mandas hacer". Entonces tomé yo de los principales de vuestras tribus hombres sabios y probados, y los constituí vuestros cabos, jefes de millar, de centena, de cincuentena y de decena y magistrados en vuestras tribus».

39 Éxodo, 18, 25-26: «Eligió [Moisés] entre todo el pueblo a hombres capaces, que puso sobre el pueblo como jefes de millar, de centena, de cincuentena y de decena. Ellos juzgaban al pueblo en todo tiempo y llevaban a Moisés los asuntos graves, resolviendo por sí todos los pequeños».

${ }^{40}$ Se refiere al Libro I de Samuel, cap. 9, que es donde el profeta recibe la orden de Dios de elegir a Saúl para señorear su pueblo, y donde ambos se encuentran. Samuel es el último juez y el primer profeta, así como el fundador de la monarquía. Los Libros de los Reyes están integrados por los dos de Samuel, los dos de Reyes y los dos de Crónicas o Paralipómenos, pero a veces sólo se denominan Reyes a los dos históricos que tienen ese nombre, y no al conjunto.

${ }^{41}$ Jeremías, 39, 5-8: «El ejército de los caldeos los persiguió y alcanzó a Sedecías en los llanos bajos de Jericó, llevándole preso a Nabucodonosor, rey de Babel, que estaba en Ribla, en la tierra de Jamat. El rey de Babilonia pronunció contra él su sentencia. Hizo matar en Ribla a los hijos de Sedecías a la vista de éste, dio muerte a todos los nobles de Judá e hizo sacar los ojos a Sedecías y le cargó de cadenas para llevarle a Babel. Los caldeos prendieron fuego al palacio real y a las otras casas y arrasaron las murallas de Jerusalén». La población fue deportada, si bien sus elementos más débiles recibieron un trato bien diferente, 10: «A los pobres del pueblo, que no tenían nada, los dejó NebuZardan, jefe de la guardia, en la tierra de Judá y les dio viñas y campos de labor». Sobre la tribu de Judá recaían los más altos honores. «La nobleza civil», Hidalguía, Año VI, 27 (Marzo-Abril 1958), $161-62$.

42 149. Canto a Dios y a su pueblo, ejecutor de sus designios. «¡Aleluya! Cantad a Yavé un cántico nuevo; / alabadle en la asamblea de los santos. / Alégrese Israel en su Hacedor, / alégrense en su Rey los hijos de Sión. / Canten su nombre entre danzas, / canten salmos con los tímpanos y la cítara. / Porque se complace Yavé en su pueblo / y da su salvación a los humildes. / Regocíjense los piadosos por su gloria, / cántenle aun en sus lechos. / Tengan siempre en su boca las glorias de Dios, / y en sus manos la espada de dos filos. / Para tomar venganza de las gentes / y castigar a los pueblos; / para poner en cepo a sus reyes / y encadenar con hierros a sus príncipes, / ejecutando en ellos el juicio escrito. / Gloria es ésta para todos sus santos. ¡Aleluya!» 
ción gran (h. 140) multitud de gentiles y de mujeres nobles ${ }^{43}$. San Lucas, en el capítulo 19, que cierto hombre noble se partió a una provincia ${ }^{44}$. San Marcos, capítulo 15, que vino José de Arimatea, varón noble, y pidió el cuerpo de Jesús a Pilato ${ }^{45}$. Y San Jerónimo en el prólogo sobre Isaías dice ser barón noble, curial y elocuente $^{46}$. Josefo, en el libro IV De Bello Judaico, lamentando los estragos hechos en Jerusalén dice que mataban a la gente vulgar y encarcelaban a los nobles ${ }^{47}$, y en el libro VII declarando las hazañas de Juliano romano dice ser natural de Bitinia y no ajeno de nobleza ${ }^{48}$. Aristóteles, en el libro III de las éticas, capítulo 6, confiesa haber nobleza de sangre y que por todos es tenida en honra ${ }^{49}$. Plutarco en la Vida

${ }^{43}$ Efesios, 3, 1: «Por esto yo, Pablo, estoy prisionero de Cristo Jesús por amor de vosotros los gentiles, puesto que habéis oído la dispensación de la gracia de Dios a mí conferida en beneficio vuestro». San Pablo en diversos pasajes de sus epístolas se gloría de los avances de la fe entre los gentiles.

${ }^{44}$ San Lucas, 19, 12: «Dijo, pues: Un hombre noble partió para una región lejana a recibir la dignidad real y volverse».

${ }^{45}$ San Marcos, 15, 42: «Llegada ya la tarde, porque era la Parasceve, es decir, la víspera del sábado, vino José de Arimatea, miembro ilustre del Sanedrín, el cual también esperaba el reino de Dios, que se atrevió a entrar a Pilato y pedirle el cuerpo de Jesús».

46 «Y primeramente ha de saberse de Isaías que en su lenguaje es elegante, ya que, como varón noble y de urbana elocuencia, no tiene en su estilo rasgo alguno contaminado de rusticidad; por lo que acontece, más que con los otros profetas, que la flor de su lenguaje no ha podido conservarla la traducción». JERÓNIMO (Santo, h. 340-420), Obras Completas. II. Comentario a Mateo. Prólogos y prefacios a diferentes tratados. Vidas de tres monjes. Libro de los claros varones eclesiásticos, Introducciones, traducción y notas de Virgilio Bejarano, Madrid 2002, 499. El prólogo a la traducción del hebreo de Isaías es de 408.

${ }^{47}$ La frase de Melio puede inducir a error, pues la población pereció sin distinción alguna a manos de zelotas e idumeos. «No se contentaba el atrevimiento de éstos con matar y desnudar a los hombres; pero aun se alargaban a matar, no escondidamente ni de noche, ni a gente particular o cualquiera, antes a los más nobles». Más adelante: «prendieron a los varones nobles, sin ser acusados por ninguno de la ciudad, y pusiéronlos en cárceles muy injustamente; y después sin doblarse, sin perder su fiereza con los ruegos y consejos que les daban, los mandaron matar». «No se hartó con esto la ira de los idumeos, antes volvieron sus manos y sus fuerzas contra la ciudad, y robaban todas las casas; y al que acaso hallaban, luego le mataban. Pensaban ser por demás las muertes de todo el pueblo, por lo cual hacían diligencia en buscar a los pontífices; en esto se ocupaba la mayor parte; y en la hora que los hallaban, luego eran despedazados». Josefo, Flavio (h. 37-97), Guerra de los judíos y destrucción del templo y ciudad de Jerusalén [De Bello Judaico], trad. y notas de Juan Martín Cordero, Barcelona 1985, vol. II, lib. IV, 5, p. 20, 6, p. 30, 7, p. 34.

48 «Un capitán de cien hombres, varón noble de Bitinia, llamado Juliano, el cual fue el más fuerte de ánimo, y más diestro en las cosas de la guerra y más esforzado en las fuerzas de sus brazos de cuantos yo conocí en esta guerra, cuando vio que los romanos resistían tan mal y que ya volvían atrás, estaba éste por causa de Tito en la torre Antonia, saltó muy pronto en medio, y persiguió él solo a los judíos que ya iban venciendo, hasta la parte de más adentro del templo». Ídem, vol. II, lib. VII, 3, p. 124.

49 «Y assi dize Aristoteles que la nobleza es vn honor que se hereda de los passados, y vna virtud del linage adquirida, y ganada con las propias obras, y por tanto es tenida en mucho». GUARDIOLA, Juan Benito (O.S.B., $\dagger 1600$ ), Tratado de Nobleza, y de los Titvlos y Ditados que oy dia tienen los varones claros y grandes de España. Compvesto por Fray... monje professo del Monasterio de Sant Beni- 
de Teseo dice que gobernando Atenas dividió los nobles de los plebeyos, dando a los nobles facultad de entender en las cosas sagradas y magistrados, denegando esto a los plebeyos ${ }^{50}$. San Agustín, libro 26, dice que hubo diferencia y contienda entre los nobles de los Herachienses y los plebeyos ${ }^{51}$. Valerio Máximo hablando de / Marco Emilio, libro VIII, capítulo 1, dice que siendo acusado no le condenó el juez por la antigua nobleza de su linaje ${ }^{52}$. El mismo en el libro III, capítulo 4, trata de aquellos que descendiendo de gente humilde por sus hazañas han alcanzado honra y nobleza ${ }^{53}$, y en el mismo libro, capítulo 5, trata de los que descendiendo de padres

to el Real de Sahagun. Dirigido al Principe Don Philippe hijo del Catholico Rey Don Philippe nuestro Señor, En Madrid, por la viuda de Alonso Gomez, 1591, fol. 61 vto. Ver ARISTóteles (384-322 a. de C.), Retórica, Introducción, traducción y notas de Quintín Racionero, Madrid 1990, lib. II, cap. 15, 387. Entre los tratadistas nobiliarios era habitual recurrir «a la autoridad de Aristóteles para vincular nobleza con virtud y relacionar ambas con la honra». CARRASCO MARTínEZ, Adolfo, «Herencia y virtud. Interpretaciones e imágenes de lo nobiliario en la segunda mitad del siglo XVI», Las sociedades ibéricas y el mar a finales del siglo XVI. Congreso Internacional, Madrid 1998, Tomo IV. La corona de Castilla, 242.

50 «Y de Teseo en la fundacion de Athenas, refiere Plutarco auer hecho lo mismo [dividir a las gentes en nobles y plebeyos], y por este orden todas las demas naciones, y Republicas de gentes han tenido, y tienen esta diferencia de estados: pues de otra manera mas seria confusion, que gouierno político». Moreno, Discvrsos de la Nobleza, h. 4 vto. «No, por cierto, descuidó que la democracia no resultara en desorden y confusa por la muchedumbre que fue irrumpiendo sin criterio selectivo, sino que previamente separó a los Eupátridas, los geómoros y los demiurgos, y encomendó a los Eupátridas las funciones de entender en los asuntos divinos, proporcionar magistrados y ser maestros de las leyes y exégetas de cuestiones santas y sagradas, poniéndolos como en un plano de igualdad con los restantes ciudadanos; ya que, al parecer, eran los Eupátridas superiores en opinión, los geómoros en utilidad y en cantidad los demiurgos». Plutarco (46-h. 120), Vidas paralelas. I. Teseo. Rómulo. Licurgo. Numa, Introducción general, traducción y notas por Aurelio Pérez Jiménez, Madrid 1985, 186.

${ }^{51}$ Herachienses sin duda se refiere a habitantes de Heraclea. ¿A qué libro 26 puede referirse Melio? ¿Puede tratarse en realidad de una carta? Ciertamente la carta 26 tiene algún pasaje -especialmente en el poema de Licencio- que remotamente podría tener alguna semejanza. ¿Aludirá a un sermón? Nada aparece en el sermón 26. ¿Puede proceder la frase de la Ciudad de Dios? Difícilmente, pues sólo tiene 22 libros. Este callejón sin salida debe obedecer a inexactitudes en la traducción de San Agustín de la que recoge la frase Melio. Agradezco al erudito agustino el profesor Padre Pedro Langa sus inestimables orientaciones sobre esta cita.

52 «Marco Emilio Escauro, acusado de concusión, presentó ante el tribunal una defensa tan desesperada y lamentable que, cuando el abogado de la acusación le dijo que, según ley, podía llamar a declarar a ciento veinte testigos, y que no se opondría a su absolución si era capaz de nombrar a otras tantas personas a las que no hubiera quitado nada durante su administración de la provincia, no pudo beneficiarse de tan inmejorable condición. Con todo, fue absuelto en atención a su antiquísima nobleza y al recuerdo aún vivo de su padre». Marco Emilio fue gobernador de Cerdeña en 55. En su defensa participó, entre otros, Cicerón. Valerio Máximo, Publio (Siglos I a. de C.-I d. de C.), Hechos y dichos memorables II, Introducción, traducción y notas de Santiago López Moreda, María Luisa Harto Trujillo y Joaquín Villalba Álvarez, Madrid 2003, 68.

${ }^{53}$ El título del capítulo es «Sobre aquellos que, de origen humilde, llegaron a ser ilustres». Ídem, vol. I, 228-32. 
nobles no han procedido como tales ${ }^{54}$. Al fin, no hay orador, historiador, poeta, ni libro que trate de santos, de emperadores, de reyes, capitanes o filósofos que deje de publicar haber habido siempre nobleza, en todos tiempos y en diversas naciones y traen para ello muchas autoridades. Clitobio ${ }^{55}$, Rajo, Certilo, Jerónimo, Orosio ${ }^{56}$, Tiraquelo $^{57}$, Casaneo ${ }^{58}$ y otros doctores, en los tratados que hicieron de nobleza, confiesan ser cierto lo referido.

\section{De la definición de la nobleza de sangre, su fundamento y derivación}

La nobleza de sangre es una claridad que viene por linaje, un loor que sale de los méritos de los progenitores, una antigua virtud y una distin (h. 141) ción de libre pechero. Tiene un fundamento de claros y heroicos varones que se ilustraron con hazañas y hechos notables y famosas victorias y virtudes insignes que tuvieron, porque alcanzaron estimación entre las gentes. Boecio, en el libro de consolación, prosa VI, dice que la nobleza es un valor y claridad que viene de los antepasados y

\footnotetext{
54 «Sobre los que, nacidos de padres ilustres, degeneraron». Ídem, 232-34.

55 Se refiere a Clicthove, Josse (Teólogo, Matemático, h. 1472-1543), De vera nobilitate opusculum completam ipsius rationem explicans \& virtutes quae generis nobilitatem imprimis decent ac. exornent de promens..., Parisiis, s.i., (1512), XXX h. in-4. ${ }^{\circ}$ Fue uno de los primeros en combatir las ideas de Lutero.

${ }^{56}$ Creemos que aquí Melio cita mal. Debe tratarse de un único autor: OsoRio, Jerónimo (Obispo de Silves, 1506-1580), Hieronymi Osorii Lvsitani De nobilitate Civili, Libri dvo. Eiusdem de nobilitate Christiana Libri tres, Olyssipone, apvd Ludouicum Rodericum Typographum, 1542, $112 \mathrm{~h}$. in-4. ${ }^{\circ}$ $(20 \mathrm{~cm}$.). Brillante tratadista y uno de los más grandes historiadores portugueses del siglo XVI. Su manejo del latín le valió el sobrenombre de «Cicerón portugués». Sigue la línea de los juristas franceses e italianos. De ser dos autores distintos, repetimos que algo muy improbable, con Jerónimo podría aludir a JIMÉNEZ DE URREA, Jerónimo (Militar, 1503-1565), Dialogo de la verdadera honrra militar que tracta como se ha de conformar la honrra con la consciencia, Venecia, Joan Grifo, 1566, 1 vol. in- $4 .^{\circ}$ En esta obra combate el duelo personal. Sobre su idea de nobleza ver CARRASCO, «Herencia y virtud», 245-46.

57 Tiraqueau, André (Jurista, Consejero del Parlamento de París, h. 1480-1558), Andreae Tiraqvelli, regii in cvria parisiensi senatoris Commentarii de Nobilitate et Ivre Primigeniorvm, Tertia hac eadémque postrema editione, ab auctore ipso diligentissimè recogniti, \& tertia ampliùs parte locupletati. Cvm indice copiosissimo, Lugdvni, apvd Gvglielmvm Rovillivm, 1584, [16]-690-[50] p. infol. (38 cm.). Ejerció una enorme influencia en la tratadística nobiliaria del siglo XVII y sobre todo entre los juristas, como Otálora.

58 Cassanaeus, Bartholomaeus (Jurisconsulto, Magistrado, 1480-1541), Catalogus Glorice Mundi, D. Batholomaei Cassanaei, Bvrgvndi, apvd aqvas sextias in Senatv Decvrice prasidis ac viri clarissimi, in qvo doctissime simvl et copiosissimè de Dignitatibus, Honoribus, Prarogatiuis, \& Excellentia, Spirituum, Hominum, Animantium, reumq, caterarum omnium, quжe Colo, Mari, Terra, Infernoq, ipso continentur, ita disseritur,..., Francoforti, ad Mœnum, impensis Sigismundi Feyrabendis, 1586, [10]-369-[1] fol. in-fol. (32'5 cm.). Fue abogado en Borgoña, consejero del Parlamento de París (1531) y primer presidente del Parlamento de Provenza (1532).
} 
una notoriedad de ella ${ }^{59}$. Y así, hablando San Jerónimo contra Elvidio hereje dice que está hecho noble en la maldad, tomando aquí noble por conocido ${ }^{60}$. Concuerdan en esto Tiraquelo en el De Nobilitate y Casaneo en el Catalogus Gloria Mundi que a un linaje cuando tiene nobleza, la notoriedad y el afirmarlo lo hace claro, porque de otra manera sería oscuro. Los emperadores, reyes y grandes señores se llaman nobles por ser conocidos. Los hijosdalgo traen por renombre el ser notorios, que poco le aprovecharía a una familia ser noble si no fuese conocida. De esta fuente de la nobleza salieron muchos arroyos que con el discurso del tiempo se hicieron ríos caudalosos, como son claro, ilustre, ínclito, / sublime, insigne, famoso, generoso, los cuales y sus contrarios, que son bajo, oscuro, infame y los demás, son testimonio en favor de la nobleza. Se daban siempre a los nobles estos renombres y títulos, y así se les van continuando hoy. Justino, en libro XV, afirma que Lisímaco natural de Macedonia era de muy alto linaje ${ }^{61}$. Cornelio Tácito, en el libro II, dice haber sido Claudio César del número de los patricios por la claridad de sus abuelos $^{62}$. Valerio, en el libro IX, capítulo 1, refiere que Flavia fue noble ${ }^{63}$. Virgi-

59 «Cuán fugitivo y cuán vano sea el hombre de nobleza quienquiera lo podrá ver. Si se reduce a la fama la nobleza, ajena es. Porque la nobleza es alabanza que procede del merecer de los padres. Pues si hace al hombre claro lo que se predica dél, es de fuerza ser loados solamente los famosos. Pues la claridad ajena nunca te hará ser claro, si te faltare la tuya. E si alguna cosa buena tiene la nobleza en sí, pienso yo ser esto solo: Poner en necesidad a los de noble linaje, que se esfuercen a seguir la virtud de sus pasados». Boecio, Anicio Manlio Torcuato Severino (h. 470-526), La consolación de la filosofía [De Consolatione Philosophiae], trad. de Fray Alberto de Aguayo, edición e introducción del P. Luis G. Alonso Getino (O.P.), Madrid 1943, lib. III, prosa VI, 104.

${ }^{60}$ Ver Adversus Helvidium de Mariae virginitate perpetua (año 383), en JERÓNIMO (Santo), Epistolae et tractatus, Norimbergae, Antonius Koberger, 1495, fol. XXXIII vto.-XXXVI vto. Elvidio sostenía que María tuvo hijos de José tras el nacimiento virginal de Jesús y que el estado matrimonial, desde un punto de vista religioso, no es inferior al celibato. Además, fue uno de los críticos del ascetismo. En la obra que le dirige San Jerónimo explica el sentido del término «primogénito» aplicado a Jesús en los Evangelios y la expresión «los hermanos del Señor».

61 «Este Lisímaco había nacido en una ciertamente ilustre familia de Macedonia, pero más que por toda su nobleza fue ilustre por las manifestaciones de su valía, que en él fue tan grande que venció por su grandeza de ánimo a la filosofía misma y por la gloria de su fuerza a todos los que habían sometido el Oriente». Lisímaco fue rey de Tracia entre el 306 y el 281 a. de C. Justinus, Marcus Junianus (Siglo III), Epítome de las «Historias Filípicas» de Pompeyo Trogo [Siglo I]. Prólogos. Fragmentos [de Trogo], Introducción, traducción y notas de José Castro Sánchez, Madrid 1995, lib. XV, 3, 1-3, p. 283.

${ }^{62}$ Claudio habla al Senado el año 48 diciendo: «Mis mayores, de los que Clauso -el más antiguo-, siendo de origen sabino, fue admitido a un tiempo en la ciudadanía romana y entre las familias patricias, me exhortan a proceder con parejos criterios en el gobierno del estado, trayendo aquí a lo que de sobresaliente haya habido en cualquier lugar». TACITUs, Caius Cornelius (h. 56-120?), Anales. Libros XI-XVI, trad. y notas de José Luis Moralejo, Madrid 1986, lib. XI, 24, 1, p. 32. Atto Clauso era tenido por la gens Claudia por su fundador. El reinado de Claudio empieza en los libros perdidos (VII a $\mathrm{X})$, donde se narraba el de Calígula. La referencia al libro II es un error.

63 «Convirtió su casa en un burdel y allí prostituyó a Munia y a Flavia, ambas ilustres tanto por 
lio, en el IX de su Eneida, página 336, nombra a Sarpedón alto en linaje ${ }^{64}$. Ovidio, en la carta de Hero fol. 52, llama a Leandro notorio y claro de sangre ${ }^{65}$.

\section{¿Cómo se adquiere la nobleza?}

Se adquiere la nobleza por la claridad del linaje, con dignidad concedida por rey o emperador, por virtuosas costumbres o antigüedad de riquezas ${ }^{66}$. Y Aristóteles, en el IV de la Política, dice que son especies de la nobleza virtud, riqueza y ciencia ${ }^{67}$. Y (h. 142) la ley II de la Segunda Partida, título XXI, concluye que la nobleza viene por una de tres maneras, por linaje, saber o bondad de costumbres, y más adelante refiere: y como quiera que los que la alcanzan por su sabiduría y bondad son llamados nobles, mayormente lo son aquellos que lo han por linaje antiguo ${ }^{68}$. La ley VI de la Segunda Partida, título IX, declara: Nobles son llamados por dos maneras, o por linaje o bondad, y quien las ha ambas éste con verdad se puede decir rico hombre, pues es rico de linaje y de bondad ${ }^{69}$. Casaneo, en la octava parte del Catalogus Glorice Mundi, dice que la nobleza se adquiere por dignidad, riquezas, común

su padre como por su marido, así como al joven noble Saturnino». VALERIO, Hechos y dichos, vol. II, 132.

64 «Y al primero que le sale al encuentro [a Turno, rey de los rútulos], a Antífates, bastardo del egregio Sarpedón y una tebana, le dispara su jabalina y lo derriba en tierra». Sarpedón era rey de los licios e hijo de Zeus. Vergilius Maro, Publius (70-19 a. de C.), Eneida, Introducción de Vicente Cristóbal, trad. y notas de Javier de Echave-Sustaeta, Madrid 1992, lib. IX, vv. 695-697, p. 431.

65 «Él es, además, de noble e ilustre cuna, pero no se remonta su raza a tu odiado Ulises». Leandro era un joven de Ábido que cada noche cruzaba a nado los Dardanelos para ver a su amada Hero que vivía en Sesto. La frase se pronuncia durante el ruego de Hero a Neptuno para que respete la vida de Leandro. Ovidius Naso, Publius (43 a. de C.-17 d. de C.), Cartas de las Heroínas. Ibis, Introducciones, traducciones y notas de Ana Pérez Vega, Madrid 1994, 175.

${ }^{66}$ Está siguiendo aquí el Tratado de Nobleza de Guardiola. Ver GuILlÉN, «La tratadística nobiliaria», 100-01.

${ }^{67}$ «Y en cuanto a las clases de principales, la riqueza, la nobleza, la virtud, la educación y lo que se relaciona con esto según el mismo tipo de distinción». ARISTóteles, Política, Introducción, traducción y notas de Carlos García Gual y Aurelio Pérez Jiménez, Madrid 1998, 168. El libro IV se dedica a los diversos tipos de regímenes políticos.

$68 \ll$ E esta gentileza auian en tres maneras. La vna por linaje. La otra por saber. La tercera por bondad de costumbres, e de maneras. E como qer que estos que lo ganan por sabiduria, e por su bondad, son por derecho llamados nobles e gentiles mayormente lo son aquellos que lo han por linaje antiguamente». Alfonso X el Sabio (Rey de Castilla, 1221-1284), Las Siete Partidas del Sabio Rey Don Alonso el nono, nueuamente Glosadas por el Licenciado Gregorio Lopez del Consejo Real de Indias de su Magestad, Impresso en Salamanca Por Andrea de Portonaris, Impressor de su Magestad, 1555, vol. I, fol. $71 \mathrm{r}$.

69 «E nobles son llamados en dos maneras. O por linaje, o por bontad. E como quier que el linaje es noble cosa la bondad passa e vence, mas quien las ha ambas, este puede ser dicho en verdad rico ome: pues que es rico por linaje, e ome cumplido por bondad». Ídem, fol. $23 \mathrm{r}$. 
reputación, privilegio, lugar, adopción, milicia, clericatura o prescripción de tiempo $^{70}$. Aristóteles, libro IV de su Política, capítulo 8, dice que la nobleza es una antigua virtud $^{71}$; y Séneca, epístola 88 a Lucilio: los hombres virtuosos mediante su grande excelencia se pueden decir bienaventurados, porque la virtud ensalza al hombre y le pone sobre las estrellas ${ }^{72}$. Petrarca, en el prospera y adversa fortuna, dice la nobleza es una antigua virtud, la cual se alcanza por uso ${ }^{73}$. / Por la virtud y fortaleza se le dio la corona a Pertinax ${ }^{74}$, y otros por sus virtudes fueron emperadores y reyes. Que se adquiera la nobleza con riquezas no se niega cuando con ellas se muestra valor. Josefo, en el VII de Bello Judaico, dice ser Antípatro idumeo, por linaje principal entre las gentes y noble mediante riqueza ${ }^{75}$. Dante, excelente poeta

70 Cassanaeus, Catalogus, fol. 180 vto.-200 [190] vto.

71 Escribe Aristóteles: «tres son los elementos que se disputan la igualdad del sistema político: libertad, dinero y virtud (el cuarto, que se llama nobleza, va unido a esos dos, pues nobleza consiste en antigua riqueza y virtud), es obvio que a la mezcla de estos dos sectores, los ricos y los pobres, hay que darle el nombre de república, y a la de los tres, aristocracia, más que a los demás, salvo a la verdadera y primera». ARistóteles, Política, 175.

72 «Mas estas artes no se ocupan de la grandeza del alma, no se alzan a lo divino, ni desdeñan lo fortuito: la virtud enaltece al hombre y lo sitúa por encima de las cosas que acarician los mortales; ni ambiciona, ni teme con exceso lo que éstos califican de bienes o de males». SÉNECA, Lucio Anneo (4 a. de C.-65), Epístolas morales a Lucilio. II, trad. y notas de Ismael Roca Meliá, Madrid 1989, lib. XIXIII, Epístola 87, p. 81. En estas epístolas se evidencia su entusiasmo por la virtud, única fuente de la felicidad. «La virtud de cada vno es la que ennoblece, y leuanta. ... Que el hombre deue mirar, no de adonde vienen las cosas, sino adonde van. Si alguna ay que haga la vida bienauenturada, aquella es que por sí no se corrompe, ni daña». Melio, Dotrina, Epístola 31, h. 60 r.

73 «¿Quieres, pues, que la gloria sea verdadera? Haz que la virtud, cuya sombra es, sea firme y verdadera». PETRARCA, Francesco (1304-1374), De los remedios contra próspera y adversa fortuna [De remediis utriusque fortuna], en Obras. I Prosa, ed. de Francisco Rico, trad. de Francisco de Madrid, Madrid 1978, 441.

${ }^{74}$ Se trata del emperador romano Publius Helvius Pertinax (126-193), que subió al trono después del asesinato de Cómodo y que permaneció en él hasta ser asesinado el 28 de marzo de 193, tan sólo 87 días después de su elección. Sobre él se escribió Comedia de los Viçios de Comodo, emperador Romano, y su muerte, y eleçion de Pertinaz y triumfo suyo en Roma, Siglos XVI-XVII, fol. 111-128 $21 \mathrm{~cm}$. [Manuscrito, Madrid, Biblioteca del Palacio Real, II/463 (6)] Asimismo contamos con Una década de Césares (Valladolid, Juan de Villaquiran, 1539) del Obispo de Mondoñedo Antonio de Guevara (1480-1545) quien le dedica diez capítulos a su figura. Los asesinos de Cómodo se dirigen a casa de Pertinax y le ofrecen el imperio diciéndole: «Lo que nos ha movido a elegirte y darte el imperio es ser como eres anciano, cuerdo, esforçado, virtuoso, rico y experimentado, y sobre todo amado y desseado del pueblo, porque el príncipe que no es a su pueblo accepto será de muchos desobedescido y de muchos más desacatado». Y uno de los mismos dirigiéndose al ejército afirma: «Aclarando, pues, más mi ánimo, digo, allende de lo que tengo dicho, que, si mi parescer se toma en este caso, devríamos poner los ojos en Publio Pértinax, en el qual concurren todas las condiciones que hemos dicho, es a saber: naturaleza, edad, gravedad, sciencia y experiencia; y que esto sea verdad, no ay para creerlo otro mayor testimonio que es averle tenido Cómodo por enemigo». Ver GuEvarA, Antonio de, Libro áureo de Marco Aurelio. Década de Césares, Madrid 1994, 596-97 y 601.

75 «Creció en todos sus enemigos el miedo, al ver que mandaba, y que había alcanzado el señorío 
y filósofo, afirma ser la nobleza antigua riqueza ${ }^{76}$. Horacio, libro II, sátira segunda, el que tuviere riqueza será claro ${ }^{77}$. La nobleza sin riqueza es casi muerta. Y Tiraquelo que es manca y muda ${ }^{78}$. Pero que la nobleza se alcanza sin riqueza por dignidad dada por rey o príncipe parece por los títulos que los romanos dieron a los cónsules, y los reyes a los ilustres por donde quedaron nobles y claros. El obispo don Alfonso de Cartagena, en el libro de Decisiones, funda que una de las cosas en que hay más conocimiento de haber habido nobleza es la dignidad y antigüedad de tiempo, presuponiendo que las dignidades concedidas por los reyes son, y han sido, por virtudes que en sus súbditos conocieron (h. 143), claridad, ciencia y hechos de $\operatorname{armas}^{79}$. Mal puede permanecer la república donde no hay ni se da honor a los buenos y castigo a los malos. Así que todas las cosas referidas son y han sido parte para conseguir la nobleza, pero con el largo tiempo se suele perder la memoria de los

tan contra la esperanza que tenían, aunque principalmente a Antípatro, el cual era mal visto delante de Aristóbulo y muy aborrecido. Era éste de linaje idumeo, principal entre toda su gente, tanto en nobleza como en riqueza». Josefo, Guerra, vol. I, Lib. I, 5, p. 34. La referencia de Melio es pues errónea. Josefo emplea palabras similares en otro pasaje en sentido contrario: «En estos mismos días, uno de los judíos, varón pequeño de cuerpo y de gesto feo, hombre de poco, no menos en linaje que en hacienda, llamado por nombre Jonatás, saliendo hasta el monumento del pontífice Juan, habló muchas cosas soberbiamente contra los romanos». Ídem, vol. II, Lib. VII, 5, p. 131

${ }^{76}$ El emperador Federico II (1194-1250) «preguntado sobre la definición de nobleza, respondió que nobleza era riqueza antigua y buenas costumbres». DANTE ALIGHIERI (1265-1321), El convite, en Obras Completas, trad. de José Luis Gutiérrez García, Madrid 1956, Tratado IV, 809. En este tratado IV Dante se refiere pormenorizadamente a la definición de nobleza propuesta por Federico II.y a la de otros, «de entendimiento más liviano aún», que eliminaron las buenas costumbres y sólo dejaron «la riqueza antigua» para refutarlas. Nos recuerda que la autoridad del emperador no se extiende al campo de la filosofía, y que por tanto no es función suya definir.la nobleza. Ni la riqueza ni la antigüedad, agrega, son requisitos de la nobleza. Para él, la nobleza es un don divino, fuente de las virtudes morales, y es propia de los individuos, no de las familias, por lo que no puede ser hereditaria. Por tanto Melio cita a Dante, pero no en el sentido correcto.

${ }^{77}$ La cita es errónea, pues corresponde al libro II, sátira tercera, 95-98: «Virtud, fama, honra, lo divino, lo humano obedecen a la hermosura de las riquezas. Quien las amase, será ilustre, valiente, justo, sabio e incluso rey y lo que quiera». Horatius Flaccus, Quintus (65-8 a. de C.), Sátiras. Epístolas. Arte poética, ed. bilingüe de Horacio Silvestre, Madrid 1996, 247. Las palabras de Melio son una traducción casi literal de «quas qui construxerit ille / clarus erit».

78 «Et profecto nobilitas sine diuitiis admodum manca est \& mutila». TIRAQUEAU, Commentarii de Nobilitate, cap. XXV, 149.

${ }^{79}$ La referencia alude a una «repetitio» pública que realizó Alfonso de Cartagena (Alfonso García de Santamaría, Obispo de Burgos, h. 1384-1456) en Aviñón el 19 de julio de 1434 camino del Concilio de Basilea (1431-1449) sobre los derechos de la caballería. El libro de Decisiones se halla en el códice donde se recogen documentos sobre el citado concilio, depositado en la catedral de Burgos (manuscrito 11): Decissiones et alia ad consilium Basilense spectanto, fol. 18 vto.-135 vto. Ver MorRás Ruiz-Falcó, María, «Repertorio de obras, mss. y documentos de Alfonso de Cartagena (ca. 1384-1456)», Boletín bibliográfico de la Asociación Hispánica de Literatura Medieval, 5 (1991), 223-24. 
antiguos linajes y el principio de cada uno, cuando la virtud y valor no se continúa y falta el haber y riquezas.

\section{Cuánto sea el valor de la nobleza y su estimación}

La nobleza es un freno que nos detiene de hacer cosas viciosas, siguiendo en esto su natural costumbre. Es cimiento de las virtudes y defensa para los vicios, y tan fuerte que apremia a seguir la misma virtud, para adquirir la gloria de los antepasados. Grande espuela es para alcanzar la virtud y seguirla ser nacidos de padres nobles. Siempre Alejandro Magno tuvo en la memoria el nombre de su padre / Filipo ${ }^{80}$, Escipión el menor se gloriaba de ser nieto de Escipión el mayor ${ }^{81}$, y así por esto hicieron hechos notables. A Octavio Augusto incitaba más la fama de su tío Julio César ${ }^{82}$. En ninguna cosa mayor pueden los hijos suceder a los padres que en la gloria y alabanza de sus heroicos hechos. Así lo dice Cicerón en el libro De officiis. Y es regla de filosofía que los de un linaje son semejantes a aquellos de quien vienen siguiendo la fuerza y propiedad de su principio, porque no hay animal que no corresponda a su ser y naturaleza ${ }^{83}$. El que de noble sangre proviene pocas veces se aparta de la virtud y bondad de sus pasados, y siempre se halla en él el esfuerzo, generosidad y crianza, clemencia para perdonar y una disposición y facilidad para todo aquello que a la claridad y resplandor de la virtud conviene.

${ }^{80}$ Alejandro Magno (356-323 a. de C.) creció a la sombra de la gloria y del talento de su padre Filipo II de Macedonia (h. 382-336 a. de C.), a quien admiraba e imitaba, pero con el que no debemos olvidar que tuvo serios enfrentamientos. Ver CARATINI, Roger, Alejandro Magno, Barcelona 2003, III. «El padre rival (343-336 a. C.)», 79-101.

${ }^{81}$ Publio Cornelio Escipión Emiliano, llamado el Africano Menor o Numantino (h. 185-129 a. de. C.), era hijo de Paulo Emilio, que fue adoptado por Publio Cornelio Escipión el Africano (235-183 a. de C.).

82 Octavio (63 a. de C.-14 d. de C.), conocido con el apelativo de Augusto, era hijo adoptivo de César desde el año 45, tomando entonces el nombre de Cayo Julio César Octaviano. Su padre -Cayo Octavio- estuvo casado con Atia, una sobrina de César. Fue el primer emperador de Roma entre el 27 a. de C. y el 14 d. de C. «Resolvió, á ejemplo de su padre, sacrificar todo lo que poseia, vender sus tierras y villas, en una palabra, arruinarse para comprar el poder soberano». DRIOUX, Compendio de la Historia Romana desde la fundacion de Roma hasta la invasion de los barbaros para el uso de los establecimientos de segunda enseñanza, Gerona, Imprenta de J. Grases, 1855, 288.

${ }^{83}$ Cicerón escribe a su hijo Marco: «Porque tienes a todos en una grande expectación de que imites mis desvelos, mis honores y, acaso también, mi fama». CiCERón, Marco Tulio (106-43 a. de C.), Los Oficios 5 ed., Madrid 1980, lib. III, cap. II, 122. Esta obra es tanto una exhortación a su hijo como un compendio de moral práctica. En lib. I, cap. XXIII, entre las cualidades que forman un hombre grande enumera la magnanimidad, el ánimo, la sabiduría, la prudencia, la justicia y la fortaleza. 


\section{De las virtudes especiales de que participa la nobleza}

Se le dieron a la nobleza en tenencia muchas gracias (h. 144) y excelencias, como son lealtad, verdad, magnanimidad, magnificencia, fortaleza, justicia, sabiduría, osadía y vergüenza. Lealtad la tienen los nobles y así por leales les dan castillos y casas fuertes en tenencia debajo de la fe con que los reciben. Ley VII de la Segunda Partida, título XVIII, que cuando algún alcaide ${ }^{84}$ hace ausencia y deja la fortaleza encargada a noble, aunque se perdiese queda libre, tanto crédito tiene la virtud de los nobles ${ }^{85}$. Los godos con sólo la palabra de los que lo eran les daban sus casas por prisión cuando cometían delitos ${ }^{86}$, y lo mismo se guarda hoy en algunos $\operatorname{casos}^{87}$. Dieron antiguamente los hijosdalgo palabra por ellos y sus descendientes de no ir los unos contra los otros, si no fuese haciéndoselo saber nueve días antes e interviniendo para ello licencia real, y no cumpliéndolo caían en caso de aleves y podían ser desafiados ${ }^{88}$. Siempre reinó la magnificencia en los nobles, mostrándolo en sus gastos, y puesto que en algunos haya pobreza no del todo se oscurece en ellos esta virtud, y siempre dan a entender lo mucho que harían / teniendo, porque la gloria del magnífico es dar y su afrenta el recibir. La magnanimidad cabe en los nobles por aquella grandeza de ánimo que nunca les falta para emprender grandes hechos y cualquier cosa que buena y honesta sea. Permanece en los nobles la fortaleza llevando por fin principal la virtud y esforzándose con discreción considerando los fines, principios y medios, resistiendo el ímpetu de la ira con el dictamen de no hacer vileza, porque la fortaleza no consiste en las fuerzas corporales, sino en el valor y hábito del corazón dispuesto para resistir y vencer

\footnotetext{
${ }^{84}$ Sobre los barones y castellanos o alcaides ver GuARDIOLA, Tratado de Nobleza, h. 117 r.-118 vto.; Salazar y Mendoza, Pedro de (1549-1629), Origen de las dignidades seglares de Castilla y Leon con relaçion Summaria de los Reyes de estos Reynos: de sus actiones: casamientos: hijos: muertes: sepulturas de los que las han creado y tenido y de muchos Ricos Homes confirmadores de priuilegios \& c. Para el Principe de España Don Filipe nuestro señor. Por el doctor..., En Toledo, Por Diego Rodriguez de Valdiuielso, impressor de el Rey nuestro señor, 1618, fol. 30 r.

85 Alfonso X, Las Siete Partidas, vol. I, fol. 57 r.-vto.

86 «Las distinciones de clase se encerraban en la ley penal: mientras que al hombre libre más importante se le dispensaba un determinado trato, al ingenuus corriente se le dispensaba otro bien diferente por el mismo delito, y muy distinto también a su vez al esclavo». KING, Paul David, Derecho y sociedad en el reino visigodo, Madrid 1981, 184. Lo que oculta Melio es que las penas económicas que recaían sobre ellos también eran superiores, y que en modo alguno el noble visigodo gozaba de privilegios legales, sino antes mayores responsabilidades. Ver ídem, 210-12.

87 Ver Alfonso X, Las Siete Partidas, vol. III, Séptima Partida, título XXIX, ley IV, fol. 84 r.-85 r. Lo cierto es que a pesar de que los privilegios penales de la nobleza tuvieron que enfrentarse con el rigor de Felipe II, «el reinado de Felipe III representó una relajación de las normas jurídicas en beneficio de los poderosos». Domínguez, Las clases privilegiadas, 156.

${ }^{88}$ Ver Alfonso X, Las Siete Partidas, vol. III, Séptima Partida, título III, leyes II-IV, fol. 18 vto.19 vto.
} 
cualquier temor, porque la osadía y fortaleza hace obras heroicas, sin temor de la muerte, despreciando la vida por ganar fama perpetua, y así tienen los nobles la osadía y fortaleza. La justicia les es propia, porque como dice Boecio en el libro De re militari ${ }^{89}$, los nobles antiguamente vivían en los campos en casas fuertes como defensores de los pueblos para defender al común y populares, y así su propio nombre era defensor (h. 145) porque defendían y mantenían a los pobres, viudas y huérfanos, siguiendo en todo la definición de la justicia, que es estar firme y constante distribuyendo igualmente a cada uno su derecho ${ }^{90}$. Necesaria es en los nobles la sabiduría, para con ella elegir y conservar lo bueno, apartar y desechar lo malo, así en la paz como en la guerra, porque si a todos en general conviene la sabiduría, mucho más a los nobles por ser el fundamento y fuerza del reino. La vergüenza y respeto es compañera y hermana de la nobleza. Y esta virtud le es dada para que acordándose de la fealdad y mancha que en su linaje habría haciendo cosa indebida, permanezca en la observancia de la virtud y nobleza, que así lo deben hacer aquellos que son amparo, resplandor y defensa de los reinos, y por quien se han de dilatar y ensanchar, y en quien el valor y bondad han de permanecer fiel y firmemente. Finalmente la nobleza anima y esfuerza al que la tiene, y le da alas para emprender cualquier / cosa hazañosa y digna de memoria y renombre por ser cimiento y basa sobre que se edifica y afirma la bondad.

\section{Del asiento perpetuo que hace la nobleza}

Los privilegios de la nobleza, su estabilidad y asiento, sus preeminencias y valor, y su estimación, así como cosa que alcanza tan alto y particular don, son de tanta firmeza que no basta la pobreza, su enemiga, ni la contradicción de los vicios

\footnotetext{
${ }^{89}$ El De re militari es de Flavio Vegecio, si bien esta cita no aparece en su obra. El error de Melio puede radicar tanto en el hecho de que el nivel filológico del siglo XVII era muy pobre y no eran raras las confusiones de autores y obras, como a que al tratarse de una obra que fue abundantemente glosada y comentada en la Antigüedad puedan existir manuscritos sin nombre de autor e incluso alguno que haya correspondido a Boecio. No en vano el rey ostrogodo Teodorico I (h. 454-526) encargó a Boecio trabajos en el campo de las artes, y en este contexto pudo realizar un comentario a la obra de Vegecio, siendo harto improbable que escribiera una obra ex novo.

90 «Raygada virtud es la Iusticia, segund dixeron los sabios antiguos que dura siempre en las voluntades de los omes justos, e da e comparte a cada vno su derecho egualmente». ALFONSO X, Las Siete Partidas, vol. II, Tercera Partida, título I, ley I, fol. 2 vto.

91 «Marcus Aemilius Scaurus nobilis, pauper: nam pater eius quamvis patricius ob paupertatem carbonarium negotium exercuit». Es decir: «Marco Emilio Escauro, noble, pobre: a causa de su padre que, aunque era patricio, debido a su pobreza ejerció un trabajo de carbonero». De Viris Illustribus Urbis Romae, 72, 1. Marco Emilio (h. 163-88 a. de C.) fue líder de la facción conservadora aristocrática del Senado. Todos sus biógrafos subrayan su nacimiento en el seno de una familia patricia empobrecida.
} 
a contrastarla. Plinio, en el libro de Varones Ilustres, tratando de Marco Emilio dice ser noble pobre ${ }^{91}$, y Baquílides, poeta antiguo, que el dinero y las otras cosas de casa nos faltan, pero que la nobleza en nosotros queda ${ }^{92}$. Las riquezas se gastan y consumen, pero la nobleza siempre está firme en el poseedor y sus descendientes. Le dio la naturaleza padre al hijo, pero al noble por madre la nobleza, y como el deudo de consanguinidad no se quita, así la nobleza en el noble (h. 146) no se puede mudar por ningún exceso. En algunos nobles se ha visto faltar el ejercicio de las virtudes, pero sus descendientes han quedado claros. Que hay gente nobilísima sepultada por pobreza no se niega, que esto la mudanza de los tiempos lo ha causado, pero sus sucesores son estimados por la nobleza de su sangre. Si los padres o abuelos fueron o son pobres los nietos serán ricos y sublimados, que así sucedió a muchos generosos. Usen pues de la virtud en sus trabajos, sirvan a Dios y a sus reyes, que cuando menos piensen se verán premiados.

\section{Que los emperadores y reyes son asimismo fundadores de la nobleza}

Los emperadores y reyes usando de su poderío hacen merced de las dignidades, y que los que así las reciben participan de nobleza aparece en el libro de Ester, donde dice Aquel se honra que el rey quiere honrar ${ }^{93}$. Baldo ${ }^{94}$ y otros concluyen lo mismo, y se comprueba por las dignidades que el senado romano dio de dictadores,

92 «Digo y diré que la mayor gloria la tiene la virtud; la riqueza incluso a hombres de poco valor acompaña, y gusta de henchir el espíritu humano; pero quien se conduce bien con los dioses, con esperanza de más grande gloria lisonjea su corazón. ... Aquel cuyo ánimo agitan muy ligeras ambiciones, sólo recibe honor tanto tiempo cuanto vive; en cambio, la virtud es laboriosa, pero llevada a su fin rectamente deja al hombre, incluso cuando muera, un muy envidiable monumento de buena fama». BAQuílides (h. 518-450 a. de C.), Odas y fragmentos, Introducciones, traducción y notas de Fernando García Romero, Madrid 1988, Oda a Argeo de Ceos, 79-80. «Busca cada cual su propio camino, para seguirlo y alcanzar célebre reputación. ... Lo más hermoso es ser noble varón muy envidiado por muchos hombres». Ídem, Oda a Aglao de Atenas, 125. Baquílides fue un poeta lírico griego nacido en Ceos. Compitió con Píndaro (518-438 a. de C.) por el favor del tirano Hierón de Siracusa († h. 467 a. de C.).

${ }^{93}$ Ester, 6, 6-11: «Entró Amán y el rey le dijo: «¿Qué ha de hacerse con aquel a quien el rey quiere honrar?» Amán se dijo a sí mismo: «¿A quién otro ha de querer honrar el rey?» Y contestó: «Para honrar a quien el rey quiere honrar, habrán de tomarse las vestiduras reales que se viste el rey, y el caballo en que el rey cabalga, y la corona real que ciñe su cabeza, y dar el vestido, el caballo y la corona a uno de los más nobles príncipes del rey para que vistan a aquel a quien el rey quiere honrar, y llevándole en el caballo por la plaza de la ciudad, vayan pregonando ante él: Así se hace con el hombre a quien el rey quiere honrar». El rey dijo a Amán: «Coge luego el vestido y el caballo, como has dicho, y haz eso con Mardoqueo, el judío que sienta a la puerta del rey. No omitas nada de cuanto has dicho». Cogió Amán el vestido y el caballo, vistió a Mardoqueo y le paseó a caballo por la plaza de la ciudad, gritando delante de él: «Así se hace con el hombre a quien el rey quiere honrar».»

${ }^{94}$ Se refiere al jurisconsulto italiano Baldus de Ubaldis (1327?-1400), profesor de derecho canónico y romano en Bolonia, Perugia, Florencia, Padua y Pavía. 
cónsules, maestros de caballeros, sumos pontífices, tribunos, pretores y cuestores ${ }^{95}$ / con los cuales títulos se ennoblecieron los Camilos, Brutos, Decios, Valerios, Torcuatos, Fabricios, Cornelios, Escipiones, Emilios, Scauros, Pompeyos, Césares, Catones, Melios ${ }^{96}$ y otros, y lo mismo ha sido en todas las demás partes del mundo y en estos reinos, dando los reyes títulos de condestables, almirante ${ }^{97}$, adelantado ${ }^{98}$, mayordomo mayor, alférez mayor ${ }^{99}$, rico hombre, duque ${ }^{100}$, conde ${ }^{101}$, marqués ${ }^{102}$ y otros. La mayor dignidad en lo temporal es la de emperador ${ }^{103}$, porque a ninguno obedece, salvo al Papa en lo espiritual ${ }^{104}$. Su significación es mandar y regir. El primero que se coronó fue Carlomagno ${ }^{105}$, que aunque mucho antes hubo emperadores no eran más que como capitanes generales, y a un mismo tiempo había muchos en diversas provincias, y unas veces se elegían por los pueblos, otras por el senado, no traían corona ni usaban de ceremonias imperiales, ni les duraba el oficio y título más de cuanto duraba la guerra. El primero que ordenó los derechos del imperio fue Julio César ${ }^{106}$, a quien sucedió Octavio, y así se fue por algún tiempo adqui-

${ }^{95}$ Sobre algunas de estas dignidades ver Tirol, Hans (h. 1505-1576), Del Principio y Origen de los Imperios que ha habido desde Adan con los Emperadores Romanos hasta el Rey don Fernando I de Austria con los Oficiales del Imperio, trad. del texto latino Alberto Alonso Guardo, José Ignacio Blanco Pérez, Pedro Conde Parrado, Miguel Ángel González Manjarrés, Madrid 2001 (Siglo XVI), 191-96. Se trata de la edición de un precioso manuscrito que Felipe II donó a la Biblioteca de San Lorenzo de El Escorial.

${ }^{96}$ Son personajes destacados Espurio Melio, que intentó un golpe de estado en Roma el año 439 a. de C. y fracasó; Petronio Melio, cuyo hijo fue cónsul en el 222; o Publio Melio Capitolino, tribuno militar con poder consular en los años 396 y 400.

97 Ver Guardiola, Tratado de Nobleza, h. 120 r.-120 vto.; Moreno, Discvrsos de la Nobleza, h. 71 r.; Salazar, Origen de las dignidades, fol. 65 r.-66 vto.

98 Ver SALAZAR, Origen de las dignidades, fol. 61 r.-vto.

${ }^{99}$ Ver ídem, fol. $127 \mathrm{r}$.

${ }^{100}$ Sobre el título de duque, el número de ellos en Castilla y sus privilegios ver GuARDIOLA, Tratado de Nobleza, h. 121 vto.-123 vto.; Moreno, Discvrsos de la Nobleza, h. 69 r.-70 r.; SalazAR, Origen de las dignidades, fol. 117 vto.-119 vto.

101 «Conde dira persona que procura el bien publico, y le antepone al suyo particular: pocos Condes ay de estos ogaño». SalazAR, Origen de las dignidades, fol. 94 r. Sobre este título ver ídem, fol. 94 r. -96 r.

${ }^{102}$ Sobre el título de marqués, el número de ellos en Castilla y los motivos de ser preferidos a los condes ver Guardiola, Tratado de Nobleza, h. 123 vto.-125 vto.; Moreno, Discvrsos de la Nobleza, h. 70 r.-vto.; SalazAR, Origen de las dignidades, fol. 113 vto.-117 vto.

103 Ver MoReno, Discvrsos de la Nobleza, h. 66 vto. Sobre el imperio romano-cristiano medieval ver FÁbrega Grau, Ángel (Presbítero), La idoneidad del candidato al Imperio según la doctrina y la actuación del Papa Inocencio III, Barcelona 1962, 31 p.

${ }^{104} \mathrm{Y}$ en esta línea tiene como misión la defensa de los derechos de la Iglesia. Ver FábregA, La idoneidad, 30.

${ }^{105}$ El rey de los francos Carlomagno (742-814) fue coronado Emperador de Occidente el día de Navidad del año 800 en Roma por el Papa, y posteriormente santo, León III († 816).

106 De manera paulatina concentró en sus manos todos los honores y cargos de la república: pon- 
riendo por sucesión ${ }^{107}$, hasta que (h. 147) el Papa Gregorio V, en el año de Cristo de $1002^{108}$, ordenó que la nación germánica eligiese el emperador romano, para la cual elección se crearon siete electores ${ }^{109}$, tres eclesiásticos y cuatro seglares. Los eclesiásticos son el Arzobispo de Maguncia, que es chanciller mayor del emperador en Alemania ${ }^{110}$, el Arzobispo de Colonia, chanciller mayor en Italia ${ }^{111}$, el Arzobispo de Tréveris, chanciller mayor en la Galia ${ }^{112}$. Los seglares son el rey de Bohemia, copero mayor del emperador ${ }^{113}$, el duque de Sajonia, que lleva el estoque delante, el conde Palatino, que sirve el plato ${ }^{114}$, el marqués de Brandemburgo, camarero mayor ${ }^{115}$. Y excepto el rey de Bohemia los otros seis electores van a la ciudad de Francfort en Alemania, y hacen solemne juramento de elegir el más suficiente caballero y más provechoso al gobierno del Imperio de cuantos conocen ${ }^{116}$, y cada uno de ellos, apartadamente, da su voto en presencia del canciller mayor ${ }^{117}$ del imperio (que es caballero), y cuando los cuatro están concordes en uno aquel es

tífice máximo, dictador, presidente del Senado, imperator -jefe del ejército-, etc. Ahora bien, todo esto bajo el sistema republicano.

${ }^{107}$ A su muerte Augusto no dejó sucesión directa, pero merced al sistema de adopciones usual en Roma pertenecen a su casa los cuatro emperadores siguientes: Tiberio Claudio Nerón (42 a. de C.-37 d. de C.), Cayo Julio César Calígula (12-41), Tiberio Claudio Druso Nerón (10 a. de C.-54 d. de C.) y Nerón Claudio César Augusto (37-68). Concluía así la primera dinastía imperial romana, formada por miembros de la gens Julia y Claudia.

108 Gregorio V, primer papa de origen alemán, ocupó el solio pontificio entre el 996 y el 999. El emperador en esos años, Otón III (980-1002) a quien coronó en 996, era su primo, y fue el verdadero creador de un proyecto político denominado Renovatio Imperii, en el que Roma ocupaba el centro. No en vano estableció en ella su residencia habitual desde el 999.

${ }^{109} \mathrm{Al}$ margen se lee: «Electores del Imperio».

110 «Su deber es cuidar y gobernar la cancillería de esa región que está entre Hungría y el río Rin». Tirol, Del Principio y Origen de los Imperios, 267.

111 «Su deber es cuidar y gobernar la cancillería que está más allá de Lombardía». Ibídem.

112 «Su deber es cuidar y gobernar la cancillería que se extiende a través de Lombardía hasta el Imperio Romano». Ibídem.

${ }^{113}$ Estaba encargado de abastecer de vino la casa del emperador.

114 «Conde Palatino, es lo mismo que Conde de Palacio: porque como dize la ley de la Partida [Partida Segunda, ley II, título I], en aquel lugar acompañauan a los Reyes, ya no los ay en España: y los que aora llamamos Condes Palatinos, son criados por los Pontifices, y Emperadores, y no tienen señorio, mas de vn priuilegio para poder legitimar naturales, spurios, hazer notarios, y otras cosas en la forma que nueuamente les estan reformados». Moreno, Discvrsos de la Nobleza, h. 69 r.

115 Sobre los electores seglares y sus deberes ver Tirol, Del Principio y Origen de los Imperios, 267-68.

${ }^{116}$ El procedimiento y ceremonias de elección en ídem, 269; FÁBREGA, La idoneidad, 3.

${ }^{117}$ El nombre se explica «porque recebian y remitian por Canceles todos los memoriales que se dauan a los Emperadores: o porque quando corregian los instrumentos los borrauan, y emendauan con lineas atrauesadas, que parecian celosias, redes, o canceles, rompiendolos, o testandolos, de donde se llamò la escritura Cancelada, como se llama comúnmente». SALAZAR, Origen de las dignidades, fol. $41 \mathrm{r}$. 
elegido, y cuando tres eligen a uno y los otros tres a otro / aquel a quien el rey de Bohemia diere su voto con juramento es electo. El cual va a la misma ciudad de Francfort y se pone en el campo nueve días continuos, y de tercer a tercer día se da un pregón por reyes de armas ${ }^{118}$ con trompetas, diciendo si hay alguno que contradiga la elección, y si no hay contradicción se va el electo desde allí a la ciudad de Aquisgrán, diez leguas de Colonia, la ribera del Rhin abajo, donde está el cuerpo de Carlomagno, y allí recibe la primera corona, luego va a Milán, donde recibe la segunda, y de allí a Roma donde Su Santidad confirma la elección y le da la tercera corona ${ }^{119}$. Y en tanto que no recibe más que la una o las dos se llama solamente rey de romanos, trae por armas el águila negra en campo de oro con la cabeza entera, y después de haber recibido la tercera corona se llama emperador ${ }^{120}$ y trae el águila con dos cabezas ${ }^{121}$, un mundo y sobre él una cruz y una espada que significa superioridad. El título Santísimo S. CC. M. César (h. 148) Augusto invictísimo, como lo declara Casaneo en la quinta parte del Catalogus Gloria Mundi ${ }^{122}$. El pri-

118 «Tan grande cuydado tuuieron los antiguos en el poner por orden, y regla la forma de los escudos de armas, que para ello el Emperador Carlo Magno, segun dize Hernan Mexia, ordenò, y señalò doze oficiales, y personas que llamanos Reyes de armas que las rigiessen, y gouernassen. Y dize, que esto tuuo su origen mucho mas atras, desde el tiempo de Iulio Cesar, y de Romulo, y dura hasta los nuestros: en los quales para auerse de dar semejantes oficios, se escogen hombres que sean de buen linaje, noble, y honrado, y muy leydos en las historias, sabios en las reglas, y regimen de las armas, y insianias [sic] de los nobles, y de los Caualleros, y de los Titulados, prelados, y grandes señores, y que sean de mucha lealtad, y confiança, los quales traen por insignia, y señal de sus oficios vna cota de armas con el escudo de armas del Principe cuyos vassallos son. Tienen saluo conduto para poder andar por todos los Reynos estraños. Emplazan las guerras, en las quales andan sin armas ofensiuas, acompañan el estandarte Real, ordenan los debates de los Principes, y Caualleros. Deuen saber el orden como el Rey haze hidalgos, caualleros, titulados, y grandes, y a todos les ordenan las insignias, y armas que han de traer». Moreno, Discvrsos de la Nobleza, h. $114 \mathrm{r}$.

119 La primera corona es de hierro, la segunda de plata y la tercera de oro. Ver TiRol, Del Principio y Origen de los Imperios, 269-71. Para el proceso de coronación ver CASSANAEus, Catalogus, fol. 133 r.-vto. Sobre la confirmación papal contamos con un excepcional documento publicado con ocasión de la coronación imperial de Carlos V, que tuvo lugar en Bolonia el 24 de febrero de 1530: $L a$ coronacion Imperial con todas sus cerimonias traduzida de latin en lengua castellana: por Diego Gracian Secretario del muy Illustre y Reuerendissimo Señor Don Francisco de Mendoça Obispo de Çamora, s.l., s.i., 1530,17 p. in-8. ${ }^{\circ}\left(34^{\prime} 5\right.$ cm.). Incluye al final láminas de la procesión imperial.

${ }^{120}$ La corona imperial es diferente de las otras, ya que «tiene una tiara en manera de mitra episcopal, sino que es más cubierta y no tan aguda, y tiene la abertura por la frente, no por las orejas; y tiene un cerco de oro por la abertura encima del cual está una cruz de oro». La coronacion Imperial..., «De las tres coronas del Emperador», 17.

${ }^{121} \mathrm{El}$ águila bicéfala fue empleada como insignia por Julio César, de modo que la misma sobre campo de oro se convirtió en la insignia de los emperadores romanos. Ver GuARDiola, Tratado de Nobleza, h. 33 vto. Otros autores señalan que la primera insignia que existió fue el águila negra en campo de oro, que era el arma de Júpiter, de quien la tomó César, y que posteriormente al dividirse el Imperio en dos partes se introdujo el águila bicéfala. Ver Moreno, Discvrsos de la Nobleza, h. 86 vto.-87 r.

122 Cassanaeus, Catalogus, Consideración 27, fol. 133 r. 
mero que se eligió por los electores fue Enrique $\mathrm{II}^{123}$. Emperador es ser vicario de Dios en su Imperio para hacer justicia en lo temporal y una de las dos cabezas de la cristiandad. Le han de reconocer los príncipes por supremo, excepto los reyes de España y Francia, por ser como son exentos por antiguo derecho ${ }^{124}$. Cuando se juntan el Papa y el Emperador van solos, el Papa al lado derecho y el Emperador al izquierdo, y hallándose presentes los reyes de España y Francia han de ir delante de ellos. La dignidad real no es tan excelente, puesto que fue la primera. Se deriva su nombre de regir y gobernar ${ }^{125}$. Rey es aquel que por herencia, o elección no habiendo heredero, o por casamiento con quien tiene derecho, o por concesión del Papa o del Emperador, tiene suma potestad en su reinado, es vicario de Dios para cumplir la justicia y mantener el reino en paz y tranquilidad ${ }^{126}$. El / primer rey que hubo después del diluvio universal fue Nembroth, le sucedió Seth, su hijo, y poco tiempo después lo fue Túbal en España ${ }^{127}$, y así es grande la antigüedad del rey en ella. A los reyes toca traer corona de oro. Su título es Majestad o Alteza, el de España Católico, el de Francia Cristianísimo, y así en cada reino les dan su renombre. La divisa es un esceptro ${ }^{128}$, que significa mando y dominio real. El título de Católico es muy alto y excede a todos los otros de los reyes. Se dice católico al que es

123 Enrique II el Cojo o el Santo (973-1024) fue elegido emperador en 1002. Tras ser proclamado rey de Germania (1002), marchó a Italia donde fue coronado rey de Italia (1004) y emperador en Roma (1014). Fue canonizado en 1146.

124 «De las quales maneras es el Reyno de España Monarchia, sin superior en lo temporal». «Y el Reyno de los Francos en Francia aunque alcanço el mismo derecho, no tuuo la misma entrada, y el alcançarlo fue mucho mas tarde». LóPEz MADERA, Gregorio, Excelencias de la Monarchia y Reyno de España. Avtor el Licenciado ... Fiscal del Rey Don Phelippe II. nuestro señor, en la Real Chancilleria de Granada. Dirigidas al Principe Don Phelippe nuestro señor, En la ciudad de Valladolid, Por Diego Fernandez de Cordoua, Impressor del Rey nuestro señor, 1597, h. 7 vto. y 9 r. Ver especialmente los capítulos II a V (fol. 6 vto.-35 r.). Sobre la mayor honra y antigüedad del apelativo de católico sobre el de cristianísimo ver ídem, fol. 82 r.-83 r.; y CAssanAEus, Catalogus, Consideraciones 28 y 37.

125 Ver Moreno, Discvrsos de la Nobleza, h. 66 vto.-67 r.

126 «De donde se colige claramente que el titulo de rey es representacion de dominio y señorio sobre muchos que viuen en comunidad de ciudades, villas y lugares, cuyo ingenio y fundacion tuuo principio desta ocasion que para que los hombres que andauan antes derramados, desparzidos y descarriados por montes, breñas, sylvas y bosques se ayuntassen y viuiessen en comunidad vnos a otros fauoreciendose y comunicando sus tratos y industrias por causa de la necesidad inuentadas aprouechassen a sus vezinos. (...) por prouidencia y don de Dios immortal alcançan la mas alta cumbre del linage humano, dando a cada vno su derecho segun su merecimiento, y tienen el lugar de Dios por hazer justicia en los Reynos de que son señores». GuARDiola, Tratado de Nobleza, h. 128 vto., 129 vto.-130 r.

127 Ver Primera Crónica..., Tomo I, cap. 1, 2 y 3, 4-7. La crónica habla de Noé, que tuvo tres hijos (Sem, Cam y Japhet). Japhet tuvo siete descendientes, el quinto de los cuales fue Túbal.

128 Desde el latín sceptrum ha derivado en el moderno cetro. 
perfecto cristianísimo y aprobado y quiere ser salvo. Como lo declara el símbolo de Atanasio $^{129}$, necesario es que ante todas las cosas crean la fe católica. Se llama la Santa Madre Iglesia Católica. Y así se da al rey de España este tan alto título por su sublime excelencia y gozan de él por haber sido cristianísimos y sobre todo católicos, los cuales como reyes más supremos, y que ellos solos conquistaron y recobraron España, nunca han hecho reconocimiento al emperador y han sido muchos ungidos y coronados con dos y tres coronas.

\section{(H. 149) De los tres estados de la nobleza ${ }^{130}$}

Ha habido en España desde el rey don Pelayo tres estados en la nobleza que son hijodalgo, infanzón y rico hombre de pendón y caldera. El infanzón ${ }^{131}$ (que es lo mismo que caballero) prefiere al hijodalgo simple y el rico hombre al caballero; y que en la nobleza haya grado de mayor y menor lo dice Casaneo en las consideraciones 15 y 39 de la octava parte de su Catalogus Glorice Mundi ${ }^{132}$. Lo mismo en las dignidades hay aumento y disminución, y antiguamente en España ha habido siempre reconocimiento de mayoría en tiempo de los fundadores cartagineses, romanos y godos, y después en su restauración, así que desde el tiempo del rey don Pelayo consta haber habido hijosdalgo, infanzones y ricos hombres, y que el hijodalgo era menos que infanzón, y el infanzón que el rico hombre. Lo mismo parece por los llamamientos que los reyes han hecho, y dicen los que de esto tratan que como antiguamente un noble hiciese en la guerra algún hecho / hazañoso se quedaba con el renombre de hijodalgo, y que esta es la derivación y principio de este apellido, y que con él tomaban divisas e insignias. La ley II de la Segunda Partida, título XXI, dice que fueron llamados hijosdalgo por ser hijos de bien, y que en ellos concurren bienes, valor y esfuerzo ${ }^{133}$. Como quiera que sea, hidalguía es en Espa-

\footnotetext{
${ }^{129}$ Se trata de un resumen de la doctrina cristiana centrado en el dogma de la Santísima Trinidad. Comienza: «Gloria a Ti, Trinidad igual, única Deidad, antes de los siglos, y ahora, y siempre. Todo el que quiera salvarse, es preciso ante todo que profese la fe católica: pues quien no la observe íntegra y sin tacha, sin duda alguna perecerá eternamente...» Este símbolo, atribuído a San Atanasio de Alejandría (padre de la ortodoxia y principal opositor al arrianismo, 296-373), es probablemente posterior al siglo IV.

${ }^{130}$ Sobre la jerarquía nobiliaria y las diferentes clasificaciones de que era objeto ver DoMínGUEZ, Las clases privilegiadas, 49-85.

131 Ver Moreno, Discvrsos de la Nobleza, h. 21 r.-vto. Es el nombre que recibieron los primeros nobles de España durante la Reconquista.

132 Ver Cassanaeus, Catalogus, fol. 182 r.-vto. y 188 vto.

133 «E porque estos fueron escogidos de buenos logares, e con algo, que quiere tanto dezir en lenguaje de España como bien: por esso los llamaron fijos dalgo, que muestra tanto como fijos de bien. E en algunos otros logares los llamaron gentiles». ALFonso X, Las Siete Partidas, vol. I, fol. $71 \mathrm{r}$.
} 
$\tilde{n ̃ a}^{134}$ lo mismo que en Italia gentileza, o llamar a uno gentilhombre ${ }^{135}$. Viene la hidalguía por linaje y descendencia de padres y abuelos y demás ascendientes paternos, y la ley II de la Segunda Partida, título XXI, dice Hijosdalgo deben ser escogidos que vengan de linaje de padre y abuelo, hasta el cuarto grado, para ser declarados por tales ${ }^{136}$. Pero ahora está limitado que baste probar de sí y del padre y abuelo venir de sangre paternal de hijodalgo, libre y exento de tributos y pechos reales y concejiles que los pecheros pagan. El valor de hijodalgo es grande y estimado, es cimiento para adquirir y en que se puede fundar cualquier dignidad, porque el honor y fama de (h. 150) la caballería depende de la hidalguía, y así los ilustres para alcanzar sus títulos, estados y señoríos se han siempre afirmado en la escala de la hidalguía.

\section{Qué es ser hijodalgo notorio de solar conocido y devengar quinientos sueldos según fuero de España}

Hijodalgo notorio es aquel que comúnmente es habido y reputado por hijodalgo entre todos los que le conocen, sin contradicción alguna, y aquel que goza de ejecutoria real litigada en contradictorio juicio. Hijodalgo de solar conocido es el que procede de casa antigua, conocida por noble en las montañas de Castilla y León, Galicia, Navarra, Aragón, Portugal, o en los llanos de estas provincias. Solar es el sitio, casa, o fortaleza, lugar, villa, o ciudad, donde algunos de los nobles hicieron asiento al tiempo de la restauración de España, para desde allí defenderse y ofender a los enemigos y recobrar lo perdido, con que adquirieron el renombre y estimación de hijosdalgo / de solar conocido ${ }^{137}$. Hijodalgo de devengar quinientos sueldos según algunos se dijo porque el conde don Sancho de Castilla mandó que los caballeros castellanos no pechasen ni fuesen a las guerras sin sueldo, el cual sueldo era de quinientos sueldos, y a los que le ganaban llamaban hijosdalgo de devengar quinientos sueldos, que es lo mismo aquel devengar que ganar. Fuese después de esto recobrando España y cesó este acostamiento ${ }^{138}$, y con él la causa del

${ }^{134}$ Sobre el principio y origen de la hidalguía, definición e hijosdalgo ver GuARDIOLA, Tratado de Nobleza, h. 59 vto.-67 vto. Una imagen de conjunto a lo largo de la Edad Moderna en Hidalgos \& hidalguía dans l'Espagne des XVI $-X V I I I^{e}$ siècles. Théories, pratiques et représentations, Paris 1989, 237-[2] p.

135 Ver Guardiola, Tratado de Nobleza, h. 67 vto.-69 r.

136 «E porende fijos dalgo deuen ser escogidos, que vengan de derecho linaje, de padre e de abuelo, fasta en el quarto grado que llaman bisabuelos». Alfonso X, Las Siete Partidas, vol. I, fol. 71 r. Melio señala erróneamente la ley III del título XXIX.

137 Ver Guardiola, Tratado de Nobleza, h. 72 vto.-75 vto.; Moreno, Discvrsos de la Nobleza, h. 25 vto. $-26 \mathrm{r}$.

${ }^{138}$ Sobre esta palabra veamos lo que escribió Juan de Valdés: «Valdés. Yo os diré. Quanto a las 
apellido, quedando en la memoria de las gentes su renombre. Otros dicen haber procedido desde cuando se rompió el fuero de las cien doncellas que los cristianos daban en tributo a los moros, impuesta por el rey Mauregato ${ }^{139}$, y que a los capitanes y gente noble que se halló en la batalla de Clavijo con el rey don Ramiro se les dieron en cada año por su vida quinientos sueldos, y que sus sucesores quedaron con este renombre. Otros que al tiempo que España comenzó a restaurarse, los que no eran para la guerra daban a los que iban a ella un tanto a manera de sueldo y acostamiento (h. 151) y que a los que militaban los llamaban hijosdalgo de devengar quinientos sueldos, y que aquellos sueldos fueron dicha soldada, y de aquí soldados. Otros que tuvo origen de los cinco maravedís que el rey don Alfonso [VIII] pidió para la guerra de Cuenca, cuando don Nuño de Lara por sí y en nombre de los hijosdalgo le contradijo ${ }^{140}$. Pero lo cierto, y en lo que concuerda el doctor Cova-

palabras, si tengo de dezir: «Honra sin provecho, sortija en el dedo», por sortija digo anillo; si puedo dezir salario, no digo acostamiento. Marcio. ¿Es lo mesmo acostamiento que salario? Valdés. Lo mesmo. (...) Valdés. Yo os lo diré. Acostúmbrase en Castilla que los grandes señores que quieren tener parte en las cibdades principales, que son del rey, procuren tener salariados, de los cavalleros que biven en ellas, los más principales y valerosos, de los quales se sirven assí en las cosas que ocurren en las cibdades donde biven, como en acompañarse dellos quando sus personas van a la guerra y quando van por alguna cosa señalada a la corte, dexándolos estar todo el otro tiempo en sus casas, y a lo que dan a estos tales llaman acostamiento. Marcio. ¿Y tienen muchos déstos? Valdés. Sí tenían antiguamente, pero ya agora que con la grandeza del Emperador no es en Castilla lo que solía, no curan tanto destas grandezas». VALDÉs, Juan de (h. 1510-1541), Diálogo de la lengua 4 ed., Madrid 1990, 227-28. La primera edición del Diálogo es de 1737, a cargo de Gregorio Mayans y Siscar (1699-1781), tras dos siglos de silencio.

139 «Para conservarse [Mauregato, muerto en 788, séptimo rey de León y de Oviedo, hijo bastardo de Alfonso I de León] en el reyno que havia usurpado á su sobrino Alfonso se confederò con Abderramen, I. del nombre, rey de Cordova, el año de 783, ofreciendole cien doncellas en tributo cada año, la mitad de ellas nobles ó 500 sueldos de oro por la que faltasse, moneda que cada uno de dichos valia 400 maravedis de los nuestros». Miravel y Casadevante, José de (Traductor, 1614-1744), El Gran Diccionario Historico, En Paris, a costa de los Libreros Privilegiados, y en Leon de Francia, de los hermanos Detournes, Libreros, 1753, Tomo VII, «Mauregato», 279. Sobre los defensores e impugnadores de la existencia histórica de este tributo ver CID HERMIDA, Luciano (1843-1914), Leyendas, tradiciones y episodios históricos de Galicia, La Coruña 1891, 143-84. El linaje de los Figueroa tiene su origen en un combate en el que dos caballeros gallegos liberaron a dos damas entregadas a los moros en pago del tributo. Ver Molina, Bartolomé Sagrario de ( $\dagger$ h. 1574-1577), Descripcion del reyno de Galizia y de las cosas notables del con las armas y blasones de los linajes de Galizia de donde proceden señaladas casas en Castilla. Dirigido al muy Ilustre señor Marichal de Nauarra, compuesto por el licenciado Molina natural de Malaga, Introducción de José Filgueira Valverde, Santiago de Compostela 1949 (1550), fol. XV; Porreño, Baltasar (Licenciado), Nobiliario del Reyno de Galicia, Introducción de Eduardo Pardo de Guevara y Valdés, Transcripción de María Dolores Barral Rivadulla y Óscar Ares Botana, A Coruña 1997 (h. 1572-1629), 236-37.

140 Nuño Pérez de Lara murió en agosto de 1177 luchando junto a Alfonso VIII (1155-1214) en el cerco de Cuenca. «Cuenca fue la primera conquista de Alfonso VIII, cuando todavía no había cumplido los 22 años; durante el sitio había fallecido el ex-regente don Nuño, que había venido orientan- 
rrubias, Obispo de Ciudad Rodrigo, en el libro de monedas, y otros que han investigado este caso, es que antiguamente estimaban las injurias a los hijosdalgo en mayor grado que a los plebeyos, devengándoles más suma de dinero ${ }^{141}$. La cual palabra devengar es verbo español gótico, y su significación llevar, y así en algunos fueros antiguos se halla escrito devengarse tanto al que hiciere tal daño. Presupuesto lo cual y que parece por la ley del Fuero Juzgo, libro VIII, título IV, que si algún hombre ha buey bravo, etc. (estimando los daños y muertes de los hombres en ciertas cantidades) en lo que toca al hombre dice que peche el señor del animal 500 sueldos $^{142}$, y la ley LXXXV del Estilo dice que el hijodalgo no ha de ser juzgado como el que no lo es, y que la pena de su deshonra sean 500 sueldos $^{143}$. El ir a la guerra contra moros sin soldada era común a todos / hasta que el año 995 el conde don Sancho de Castilla ${ }^{144}$ dio libertad a los hijosdalgo de que no fuesen a la

do las decisiones del joven rey desde el día de su mayoría de edad, durante casi ocho años». MARTíNEZ Díez, Gonzalo (S.J.), Alfonso VIII, rey de Castilla y Toledo, Burgos 1995, 124.

${ }^{141}$ El libro de monedas alude a Covarrubias y Leyva, Diego de (Obispo de Ciudad-Rodrigo, 1512-1577), Veterum Collatio Numismatum (1550), en Omnia Opera, Salmanticæ, In ædibus Dominici à Portonarijs de Vrsinis, Sacræ Catholicæ Maiestatis Typógraphi, 1576, Tomus Primvs, 991-1062. Los capítulos 5 y 6 tienen el texto en castellano. En esta obra (cap. 5, 1036) se indica: «En esta materia de sueldos y de injurias, es razon notar dos leyes del Estylo bien antiguas, pues aquella obra se hizo del tiempo del Rey don Alonso Decimo, y de las leyes que entonces se vsauan por la mayor parte, la vna es ley 85. y la otra es ley 131. por las quales paresce, que el que injuriare de palabra al home hijo dalgo ha de pagar quinientos sueldos, aunque las injurias dichas a otros hombres, que no son hijos dalgo, no tienen tanta pena. De estas leyes noto el muy magnifico y en letras, y rectitud de justicia señalado varon el Licenciado Arce de Otalora del consejo de su Magestad en su Real audiencia de Valladolid en el libro de las hidalguias. secunda part. capit. quarto. nume. vndecimo. La causa y razon porque dizen en Castilla hidalgo de vengar [sic] quinientos sueldos segun fuero de España, y que sea esta porque a los Hidalgos por su nobleza les compete este derecho especial de estimar y pedir sus injurias por quinientos sueldos».

${ }^{142}$ Libro VIII, título IV, artículo XVI. «Si el animalia que es brava mata algun omne». «Si algun omne ha buey bravo, ó toro, ó baca, ó otra animalia, mátelo luego ante que faga mal: é si lo sabe por los vecinos quel dixieren que es tal, é despues lo toviere ó lo governare, é no lo quisier luego matar, é despues matar algun omne, ó firiere, faga ende emienda al sennor, cuemo manda la ley del omecillio de los omnes, é de las mugeres, de los ninnos, é de los siervos, é de las siervas. Assí que si aquela animalia matar omne ondrado, peche el sennor por el omecillio D. sueldos». Después enumera las diferentes cantidades a pagar en función de la edad del hombre, del niño y de la mujer muertos. Sirva decir que los más «valorados» eran los hombres entre 20 y 50 años y las mujeres de 40 a 60 años, mientras que a igual edad de niño y niña esta última se evaluaba en la mitad que aquel. Fuero juzgo ó Libro de los jueces. Cotejado con los mas antiguos y preciosos códices por la Real Academia Española, Valladolid 1990, 144. Facsímil de la edición de Madrid, por Ibarra, Impresor de Cámara de S. M., 1815.

143 «Otrosi es a saber que el hijo dalgo no sera assi juzgado como otro que no es hijo dalgo. E la pena de la desonrra del hijo dalgo es quinientos sueldos». Las leyes del estilo. E declaraciones sobre las leyes del fuero, s.l., s.i., s.f., fol. XII r.

${ }^{144}$ El conde de Castilla Sancho I García (en el poder entre 995-1017) concedió numerosos privilegios a sus súbditos, hasta el punto de que se le dio el sobrenombre de «conde de los buenos fueros». 
guerra sin acostamiento, con lo cual cesó aquella preeminencia, y se olvidó la estimación y pena de las injurias, y de allí en adelante los hijosdalgo se diferenciaron de los plebeyos en no ir a la guerra sin acostamiento y en no contribuir para ellas, como lo hacían los pecheros. De manera que después que se dio esta exención a los nobles hijosdalgo de que no pechasen como los plebeyos y fuesen libres de tributos y pechos, no se ha tenido cuenta con más preeminencia ni destinación, y la devengación sólo se articula para memoria de la antigüedad. Esta es la causa por la que se dice hijodalgo de devengar quinientos sueldos ${ }^{145}$. Y porque no queden los lectores dudosos de cómo los hijosdalgo antiguamente pagaban pecho para las guerras, pondré lo que dice la Crónica general en la tercera parte, capítulo XX, tratando del conde don Sancho. Este dio a los castellanos la virtud de que no pagasen tributo ninguno, ni fuesen a las guerras sin acostamiento ${ }^{146}$, y otras crónicas hacen de ello (h. 152) mención y se comprueba con privilegios, y no es de admirar que los nobles contribuyesen entonces para las guerras y fuesen a ellas, por estar como estuvo España, hasta el conde don Sancho, en término de quedar de todo punto destruida.

\section{De las preeminencias y libertades de hijodalgo}

La principal preeminencia de los nobles fue el honor y reverencia. Las justicias no entraban en sus casas estando ellos o sus mujeres en ellas para ejecutarlos por causas civiles, puesto que les ponían plazo para salir de ellas; no sacaban prendas donde estaban ellos o sus mujeres, ni donde se hallaban sus mantos o escudos; no les apremiaban yendo a caballo a que pagasen cosa alguna; nadie quebrantaba sus casas sin expreso mandato del rey. Las injurias a ellos hechas eran de mayor pena -podría el hidalgo, y no otro alguno, desafiar, y puesto que cometiese delito por el cual debiese morir no se le daba muerte infame, salvo / interviniendo traición, aleve

\footnotetext{
145 Ver Guardiola, Tratado de Nobleza, h. 76 r.-79 vto.; Moreno, Discvrsos de la Nobleza, h. 30 vto.-31 vto. La expresión «devengar quinientos sueldos» incluso aparece como entrada en la primera edición del diccionario de la Real Academia Española en el XVIII. Ver Diccionario de la lengua castellana... tomo tercero, que contiene las letras D. E. F., En Madrid, en la imprenta de la Real Academia Española, por la viuda de Francisco del Hierro, 1732, 249.

146 Don Sancho, conde de Castilla, «dio libertad e franqueza a los caualleros castellanos que non pechassen nin fuessen en hueste sin soldadas de su señor ca antes desto pechauan en que auien a yr con el señor sin soldadas ningunas». ALFONSO X EL SABIO, Las quatro partes enteras dela Cronica de España que mando componer el Srenissimo rey don Alonso llamado el Sabio. Donde se contienen los acontecimientos y hazañas mayores y mas señaladas que sucedieron en España: desde su primera población hasta casi los tiempos del dicho señor rey. Vista y emendada mucha parte de su impresión por el maestro Florian Docampo: Cronista del emperador rey nro señor, Zamora, Agustín de Paz y Juan Picardo, 1541, fol. CCLXVIII vto.
} 
o caso cruel-, la pena del Talión no se ejecutaba antiguamente en los nobles, como lo refiere el doctor Covarrubias en el libro II de Varias resoluciones ${ }^{147}$. No son puestos a cuestión de tormento, salvo en ciertos casos dispuestos por derechos. Están exentos de pechos reales y concejiles, no pueden ser ejecutados ni prendados en las casas de su morada armas ni caballos, ni encarcelados por deudas, como no sean de rentas o maravedís del rey, o si la deuda desciende de delito. Se les da cárcel apartada de la otra gente. No se les echan huéspedes. Cuando enviudan sus mujeres son exentas de pechos, si en su viudez viven casta y honestamente. No son castigados con pena corporal por los delitos que cometen, así como lo son los plebeyos, salvo si interviniese en ellos herejía, traición o excesiva contumelia ${ }^{148}$. Siendo presentados como testigos se les da mucho crédito, y como haya suficiente número de nobles, aunque sea mayor el de los plebeyos, se les da en derecho más fe. Tienen preeminencias de ser cumplidas las donaciones por ellos hechas. Piden restauración como menores ${ }^{149}$ (h. 153) en algunos pleitos. Cuando no han alegado alguna cesión no pierden derecho, ni ellos ni sus mujeres, por prescripción de tiempo estando en la guerra en servicio del rey ${ }^{150}$. No se les compele a que vayan a la guerra si no es de su voluntad o en los llamamientos reales ${ }^{151}$. Pueden entrar en las órdenes de Santiago, Calatrava, Alcántara y San Juan. Tienen otros muchos privilegios y libertades ${ }^{152}$. Su traje y hábito solía ser diferente y más preeminente que el de la gente común y demás ciudadanos, traían en los zapatos una señal por la cual eran conocidos, los nobles romanos se señalaban trayendo en el brazo derecho escritos sus nombres, familia, ciudad y provincia donde residían ${ }^{153}$, para que si

\footnotetext{
147 Covarrubias, Omnia Opera, Tomus Primvs, Variarum Resolutionum, lib. II, cap. IX, 587.

148 «Oprobio, injúria, afrenta, ofensa de palabra dicha ò hecha cara à cara à uno». Diccionario de la lengua castellana... tomo segundo, que contiene la letra $C$, En Madrid, en la imprenta de Francisco del Hierro, impressor de la Real Academia Española, 1729, 573.

${ }^{149}$ Evidentemente se refiere a la restitución. Ver Novísima Recopilación, vol. V, lib. XI, título XIII. «De la restitucion in integrum», 208-09.

150 Ver Alfonso X, Las Siete Partidas, vol. I, Segunda Partida, título XXI, ley XXIV, fol. 76 r.vto.

${ }^{151}$ Una enumeración de las prerrogativas de la nobleza en BARRIOBERO y ARMAS, Juan (Barón de Río Tovía), La nobleza española. Su estado legal, Madrid 1902, 27-28.

152 «En efecto, la nobleza va unida a la libertad por una especie de relación oculta, aunque ésta sea muchas veces algo más floja, de manera que apenas se comprende que una pueda existir sin la otra. Por esto los duques, condes, marqueses, obispos asumen tan gran libertad que no quedan comprendidos en las reglas de derecho a no ser que se exprese especialmente (c. de multa de preben.); en este solo ejemplo se manifiesta que toda la honra de la nobleza se consagra con la propia libertad cuanto más amplia ésta sea». PozA, Fuero de hidalguía, cap. XIII, 231.

153 «E porque fuessen tenudos de guardar esto, e non errar en ello, en ninguna manera, fazian les antiguamente dos cosas. La vna que los señalauan en los braços diestros, con fierros calientes de señal, que ningund otro ome non la auia de traer, si non ellos. E la otra que escriuian sus nomes, e el linaje
} 
errasen en la disciplina militar fuesen $\operatorname{castigados}^{154}$, y si cometían algún error contra el bien público eran expelidos de la nobleza y raídos de los libros donde estaban escritos por nobles ${ }^{155}$, por lo que se queja Boecio diciendo que como a malhechor (no siéndolo) le habían raído del libro y catálogo de los nobles ${ }^{156}$.

\section{Del segundo estado de la nobleza}

/ El segundo estado de la nobleza es ser infanzón y lo mismo (según la ley XIII, de la Segunda Partida, título I) que caballero o barón ${ }^{157}$. La caballería se llama milicia por su fortaleza, y así para caballeros escogían antiguamente de mil uno, y que aquel fuese hijo de noble para que imitase a sus pasados. Estos andaban en las guerras y, cuando ya eran de anciana edad, eran ocupados en el gobierno de los pueblos. Eran llamados defensores porque defendían la tierra y la amparaban. Concurrían en ellos poderío, esfuerzo y nobleza de sangre. Los infanzones tenían derecho para ser armados caballeros y los hijosdalgo habían de hacer servicios y hechos para ello. Había antiguamente casas señaladas de hijosdalgo que seguían los pen-

onde venian, e los lugares onde eran naturales, en el libro que estauan escritos todos los nomes de los otros caualleros». Alfonso X, Las Siete Partidas, vol. I, Segunda Partida, título XXI, ley XXI, fol. 75 r. «Y porque la señal del braço derecho no podia en todo tiempo ser bastantissima señal para ser conocido el cauallero, conuino que se buscasse otra cosa mejor con que pudiesse ser diferenciado, y fue que truxesse espuelas doradas y espada guarnecida de oro, o dorada, cadena o collar y anillo de oro, y esto era mas vsado en tiempo de guerra». Guardiola, Tratado de Nobleza, fol. 103 vto.-104 r.

154 «Los escudos de cada cohorte estaban pintados de distinto modo que los de las otras, según se practica también en este tiempo, para que en la confusión de una batalla no se separasen los soldados de sus compañeros; y en la parte interior del escudo de cada soldado estaba escrito su nombre con el de su cohorte y centuria». Vegecio Renato, Flavio (Siglo IV), Instituciones militares, ed. del Cadete de Guardias Españolas Jaime de Viana (1736-1770) de Madrid, Joachin Ibarra, 1764, Madrid 1988, lib. II, cap. XVIII, 70.

${ }^{155}$ Los dos censores eran los encargados cada cinco años de revisar el cuerpo de ciudadanos (la lustratio). En el mismo sentido existía un álbum senatorial que contaba con una capa de cera o de cal, del cual se borraba, es decir se raía, a aquellos que causaban baja por muerte o por infamia o indignidad.

${ }^{156}$ La consolación de la filosofía la escribió «en medio de los mayores infortunios». «Boecio, que había llegado a la cumbre de la ciencia y del poder político, de la estimación, de la admiración, era el hombre más llamado a escribir sobre la vanidad de los atractivos humanos, al verse privado de todos y en vísperas de ser ajusticiado como recompensa de sus merecimientos». BoECIO, La consolación, 15-16. Fue ministro del rey ostrogodo Teodorico I $(\dagger 451)$, pero tras ser acusado de conspirar contra el rey fue encarcelado y sus bienes confiscados, hasta terminar sus días decapitado tras permanecer un año en prisión.

157 «Catanes evaluassores son aquellos fijos dalgo en Italia, a que dizen en España infançones. E como quier que estos vengan antiguamente de buen linaje, e ayan grandes heredamientos, pero no son en cuenta destos grandes Señores, que de suso diximos. E por ende non pueden nin deuen vsar de poder, nin de Señorio en las tierras que han, fueras ende, en tanto quanto les fuere otorgado, por los priuillejos de los Emperadores, e de los Reyes». Alfonso X, Las Siete Partidas, vol. I, fol. 7 vto.-8 r. 
dones de los ricos hombres, así como el de Lara, Castro, Manuel, Haro, y otros, llevando su acostamiento, el cual les pagaban los ricos hombres de los maravedís de oro que los reyes les daban. Esto lo quitó el rey don Juan I, y en su lugar nombró capitanes ${ }^{158}$. Solían algunos de los hijosdalgo antiguos tener (h. 154) tributos y pechos sobre pueblos y pecheros, por lo cual les llamaban deviseros, y también por tener derechos en algunos lugares de behetrías ${ }^{159}$, que por ser pueblos libres de señorío se encomendaban a ellos. Ningunas justicias entraban en sus casas a prender malhechores a quien pudiese valer la inmunidad de la Iglesia. Vedaban viviendo en aldeas realengas en cierto tiempo del año las hierbas para que las comiesen sus ganados, y tenían otras preeminencias en los mismos lugares.

\section{Del honor de la caballería ${ }^{160}$}

La caballería se instituyó para mayor alteza de la nobleza, la cual ha sido tan alta y sublime que muchos emperadores y reyes no se coronaron ni consagraron hasta ser armados caballeros. Los reyes de España no sólo han armado caballeros a los del segundo y tercer estado, pero a hijos de emperadores y reyes de Francia e Inglaterra y a otros que venían a recibir de su mano la caballería. Se daba en ocasiones de coronación o matrimonio, o cuando se había de dar alguna / batalla, y esto había de caer sobre hidalguía. El mayor premio que el rey daba a los hijosdalgo e infanzones era armarlos caballeros. Haber quedado en Castilla el nombre de caballero y perdido el de infanzón ha sido porque como recibían la dignidad y orden de caballería se fueron quedando con el título de ella y con él olvidando el primero. Se armaban para ser señalados y tener en memoria aquello a que estaban obligados. Las cortes de los emperadores y reyes en tanto más son estimadas cuanto mayor caballería reside y asiste en ellas, y así fueron instituidos los caballeros de las órdenes de Santiago, Calatrava, Alcántara, San Juan, Montesa, Cristo, los de la Banda $^{161}$, y los demás de otros reinos y coronas, para más conservación, lustre y

158 Juan I de Castilla (1358-1390) reinó desde 1379. Organizó un ejército permanente a su servicio integrado por 4500 lanzas y 1500 jinetes. Desde el punto de vista militar el principal acontecimiento de su reinado fue la derrota sufrida a manos anglolusas en Aljubarrota (1385), que significó el fin de su ambicioso proyecto de conquista de Portugal.

159 «E behetria tanto quiere dezir, como heredamiento que es suyo quito de aquel que biue enel: e puede recebir por Señor, aquien quesiere que mejor le faga». Alfonso X, Las Siete Partidas, vol. II, Cuarta Partida, título XXV, ley III, fol. $62 \mathrm{r}$.

${ }^{160}$ Sobre el origen y principio de los caballeros y órdenes de caballería, tipos de caballeros, juramento y atavío ver GuARDiola, Tratado de Nobleza, h. 79 vto.-104 vto.

161 «Las vandas condragantes que algunos ponen en sus escudos, son armas muy antiguas de los Castellanos, y son simbolo de Fortaleza, y los mas las traen por auerse hallado en la famosa batalla del Salado con el Rey don Alonso el Vltimo deste nombre, que fue el que instituyò la Orden de la 
aumento de la misma caballería. Tienen los caballeros obligación de mantener armas y caballo, y de no usar oficios viles y de defender a los menores y viudas, y a ejercitarse en otras obras de caridad y virtud, a ejemplo de Julio César (h. 155) que yendo con su potestad imperial, estando un soldado ante el juez le pidió que abogase por él en su causa y dándole el emperador otro que lo hiciese, le dijo el soldado: «Oh César, cuando yo recibí por ti estas heridas entendido tenía que me habías de defender». Por lo cual bajándose el emperador del caballo abogó por el soldado. No ha de injuriar el caballero a nadie, ni murmurar ni decir mal de otro en su ausencia, no ha de huir de la batalla ni desamparar a su rey y bandera, y viendo al rey en peligro o a pie le debe dar su caballo para que se salve, sacándole de todo peligro y prisión o haciendo para ello cuanto le sea posible. No han de entregar castillo, fortaleza, ciudad o villa donde estuvieren por alcaides, sin mandato y licencia del rey, y haciendo lo contrario pierden la dignidad y orden de caballería, e incurren en las demás penas que por derecho están establecidas.

\section{Del tercer estado de la nobleza}

El tercer estado de la nobleza que era ser rico hombre de pendón y caldera ${ }^{162}, \mathrm{y}$ lo mismo que ahora ilustre, como lo declara la ley X de la Cuarta Partida / título $\mathrm{XXV}^{163}$, y lo mismo refiere Santo Tomás en el libro Regimiento de Príncipes diciendo que en España, mayormente en Castilla, los principales después del rey eran los ricos hombres ${ }^{164}$. El nombre rico es gótico y significa riqueza y bondad, y la ley de partida dice: nobles son llamados por linaje y bondad, y quien las ha

\footnotetext{
Vanda, y la dio por armas a muchos Caualleros hijosdalgo, en memoria de la vitoria que alcançò de los Moros». Moreno, Discvrsos de la Nobleza, h. 91 r.

162 Ver Guardiola, Tratado de Nobleza, h. 111 vto.-114 r. Llamamos la atención sobre la circunstancia de que las fuentes de autoridad que siguen en el texto de Melio son las mismas que emplea Guardiola en la h. 112 vto.

${ }^{163}$ Alfonso X, Las Siete Partidas, vol. II, fol. 64 r. Melio señala equivocadamente la Quinta Partida.

164 «En España todos los príncipes ó barones principales sugetos al rey, son llamados ricos homes, principalmente en Castilla, y la razon de esto es, que el rey provee de rentas á dichos barones, segun sus merecimientos ó segun la voluntad del rey. Por esto se llaman ricos homes, porque aquel á quien el rey concede mas dones, es mayor señor, porque puede sostener mayor número de soldados». TomÁs DE AQuino (Santo, 1225?-1274), El Gobierno Monárquico, ó sea el libro De Regimine Principum, escrito por Santo Tomás de Aquino, testo latino y traducción castellana por D. León Carbonero y Sol, Director de La Cruz, Sevilla, Imprenta y Libreria de D. A. Izquierdo, 1861, cap. XXII. «De otros títulos de dignidad propios de ciertos paises y de las funciones á ellos inherentes», 336-37. Ver Moreno, Discvrsos de la Nobleza, h. 67 vto.-68 r. Hay que subrayar que cuando Melio escribe esto todavía había quien ponía en tela de juicio la autoría de Santo Tomás de Aquino, creyendo la obra posterior a su muerte. Ver SALAZAR, Origen de las dignidades, fol. 9 r.
} 
ambas se puede llamar rico hombre, pues es rico por linaje y por bondad ${ }^{165}$. Se diferencia este nombre de rico en que si se pospone (como hombre rico) significa hacienda o riquezas, pero cuando se antepone diciendo rico hombre se entiende por noble y principal del reino, y así se fue continuando este título de rico hombre en los grandes, después de la restauración de España, hasta el rey don Enrique II que comenzó a dar la dignidad de duque, pero también hubo algunos títulos de condes. Los ricos hombres de pendón y caldera se llamaban así porque traían pendones en la guerra, a los cuales seguían los infanzones de su mesnada o acostamiento a los cuales mantenían y daban de comer ${ }^{166}$. Se instituía (h. 156) esta dignidad velándose el pendón con la divisa una noche en la iglesia con gran solemnidad. Tenía honor y estimación y una suma de maravedís de oro. Gozaba de título grande. Confirmaba los privilegios reales como uno de los del Consejo ${ }^{167}$, y tanto más estimado era cuantos más infanzones tenía. Alcanzó a tener don Nuño de Lara en tiempo del rey don Alfonso el Sabio trescientos infanzones ${ }^{168}$. Quitó el rey don Juan (como queda dicho) estos acostamientos que daba a los ricos hombres, y nombró en su lugar capitanes, a los cuales se guardaban las preeminencias de los infanzones e hijosdalgo. No podían los jueces conocer de las causas criminales de los ricos hombres sin especial comisión del rey. No estaban en pie ante los jueces, sino sentados en medio de ellos. Podían aposentarse en las casas de los que no eran nobles. Armaban caballeros con licencia del rey, y cuando el rey los echaba del reino tenían cierto tiempo señalado para salir.

165 Ver Alfonso X, Las Siete Partidas, vol. I, Segunda Partida, título IX, ley VI, fol. 23 r.

166 Ver Moreno, Discvrsos de la Nobleza, h. 91 vto.-92 r. «Con el pendon les concedian facultad de hazer gente para la guerra. La caldera significaua eran poderosos para la sustentar, y mantener». SAlAZAR, Origen de las dignidades, fol. 12 r. Sobre los infanzones ver Tomás DE AQUINO, El Gobierno Monárquico, 337-38. «Estos infanzones son nobles que tienen mas poder que otros hidalgos, y han de tener mas valor que ellos y que los gobernadores de Castillos y Ciudades, siendo conocidos en algunos puntos con el nombre de castellanos».

167 Ver SALAZAR, ibídem.

168 «Et vos don Nunno sabedes que tamannas fueron las merçedes et la honra que el rey vos fizo, que llegastes a auer trezientos caualleros por vasallos, de los mejores infançones que auía en Castilla e en León e en Gallizia, así que vos érades el más poderoso omne que sennor ouiese e más honrado de Espanna». Crónica de Alfonso X, edición, transcripción y notas por Manuel González Jiménez, Murcia 1998, cap. XXX, 100-01. Nuño González de Lara (†1275), el infante don Felipe (hermano de Alfonso X) y otros nobles se reunieron en Lerma en 1269 configurando un bando nobiliario que se enfrentó a la Corona. Ver Álvarez Palenzuela, Vicente Ángel - SuÁrez Fernández, Luis, La consolidación de los reinos hispánicos (1157-1369), Madrid 1988, 83-85. Desde la llegada de Alfonso X al trono aparece en los diplomas el primero entre los nobles castellanos, y gozó del favor real. Ver GonzÁlez JimÉnEZ, Manuel, Alfonso X el Sabio (1252-1284), Palencia 1993, 45-46 y 53-54. 


\section{De las dignidades de España}

/ Príncipes en España son los primogénitos de los reyes que han de suceder en los reinos, infantes los demás hijos de los reyes ${ }^{169}$. Condestables son compañeros perpetuos de los reyes y asisten con ellos en las guerras y en los negocios arduos, retos y desafíos que en presencia del rey se hacen ${ }^{170}$. Son vicarios del rey en los ejércitos de tierra, guiadores y caudillos de ellos, y lo mismo que entre los romanos maestro de caballeros o prefectos de legiones ${ }^{171}$. Después en la restauración de España se llamaron príncipes de caballería, cuyo nombre les duró poco, y así se dijeron luego alféreces mayores y últimamente condestables. Traían las insignias de los emperadores y reyes, y lo mismo los alféreces mayores. Traían estoques desnudos delante de sí y consta de un fuero antiguo que todo rey de España hubiese alférez que tuviese su seña y cien caballeros pagados, y en casa del rey mesa de estado, y en la Pascua florida copa de oro o de plata del rey por suya, y los vestidos de aquel día. Fue el último alférez mayor de Castilla don Fernando de Castro en tiempo (h. 157) del rey don Enrique II que la dio a don Alfonso de Aragón con título de Villena ${ }^{172}$. Gozan de las preeminencias de los ilustres y hay algunos que son grandes.

Condes los hubo en tiempo de los romanos, a quien llamaron comites, y después en el de los godos, y luego que se restauró España de los moros. Asistían en el Palacio Real como los más principales, eran compañeros del rey, comían con él cuando venían a las cortes y gobernaban supremamente. Otra manera de condados dieron algunos reyes, así como tierras en feudo, con título de conde palatino, y estos de por vida, sin que la dignidad pasase al sucesor. El rey don Enrique II hizo Conde

\footnotetext{
169 Ver Moreno, Discursos de la Nobleza, h. 67 r.-vto.; SAlazAR, Origen de las dignidades, fol. 9 r.

170 Casi las mismas palabras que emplea Salazar: «Condestable, quiere dezir, Comes stabilis: Compañero, o Conde, que ha de estar siempre al lado de el Rey: otros dizen, que Conde establecido para las cosas de la guerra». Origen de las dignidades, fol. $126 \mathrm{r}$.

171 Ver Guardiola, Tratado de Nobleza, h. 118 vto.-119 r.; Moreno, Discvrsos de la Nobleza, h. 70 vto.-71 r.

${ }^{172}$ Fernando de Castro, conde de Trastámara, de Lemos y de Sarria por concesión de Pedro I el Cruel (1334-1369) el 23 de junio de 1366, fue alférez mayor y adelantado mayor de Galicia. Enrique II (1333-1379) fue el primer monarca castellano de la Casa de Trastámara (1369-1379) tras derrotar a su hermanastro Pedro I. A quienes combatieron en su bando durante la guerra civil les recompensó generosamente con las denominadas «mercedes enriqueñas». «Por otra parte se debió a Enrique II, en estas jornadas burgalesas, la creación del primer título de marqués que hubo en Castilla. Don Alfonso de Aragón, conde de Denia y de Ribagorza en los estados de la corona de Aragón, recibió en Castilla el título de marqués de Villena». Valdeón BARUQue, Julio, Enrique II de Castilla: La guerra civil y la consolidación del régimen (1366-1371), Valladolid 1966, 119. Esta obra es la tesis doctoral del profesor Valdeón. Ver también García Moratalla, Pedro Joaquín, La Tierra de Alarcón en el Señorío de Villena (Siglos XIII-XV), Albacete 2003, 117.
} 
de Narbona a don Alfonso su hijo, y a don Pedro de Trastámara, el Condado de Ribadeo, el de Carrión, el de Mayorga, el de Niebla, el de Medinaceli ${ }^{173}$. Tienen los condes las preeminencias de los ilustres y hay algunos que son grandes ${ }^{174}$.

Adelantado, según la ley XIX de la Segunda Partida / título IX es presidente de la provincia, y un juez superior para enmendar el juicio de los otros jueces, en grado de apelación, o lo mismo que hoy hacen las audiencias reales, y además de esto sosegaba los bullicios y escándalos ${ }^{175}$. Visitaba la tierra y castigaba a los malhechores, y era capitán general en la frontera de moros. Las partes donde hubo y hay adelantado son estas: Castilla, León, Galicia, Andalucía, Murcia, Granada, y en las Indias hay también adelantados. También hoy hay títulos de vizcondes, los cuales tenían las veces de los condes ${ }^{176}$.

Mariscales se crearon en tiempo del rey don Juan I. Se les dio título de ilustres, pero no se han tenido después acá en tanto, aunque en Francia y Navarra son títulos preeminentes. Su oficio es marchar con el campo. Tienen en los ejércitos poder de capitanes generales y usan de la misma jurisdicción. Son aposentadores de las huestes y gozan de la dignidad de ilustres ${ }^{177}$.

173 «Los títulos recaerán sobre los caudillos extranjeros o sobre sus parientes, a los que hace condes. Con estas medidas el primer Trastámara aumentó notablemente el número de condes perpetuos existentes en el reino de Castilla. (...) Los parientes próximos de Enrique II lograron grandes concesiones: ... su hijo bastardo don Alfonso Enríquez Noreña y Gijón, igualmente con categoría de conde». VALDEÓn, Enrique II, 118-20. Los titulares de algunos de estos condados fueron: Trastámara, Pedro Enríquez; Ribadeo, Pierre de Vilaines; Carrión, Juan Sánchez Manuel; Mayorga, que dio origen al ducado de Benavente, cuando Enrique IV el 25 de enero de 1473 concede este título a D. Rodrigo Alonso Pimentel, cuarto Conde de Benavente y tercer Conde de Mayorga; Niebla, Juan Alfonso de Guzmán; Medinaceli, Bernal de Bearne. Ver SuÁrez Fernández, Luis, Nobleza y monarquía. Puntos de vista sobre la Historia castellana del siglo XV, Valladolid 1959, 18-21.

${ }^{174}$ Sobre el título de conde y su número en Castilla ver Guardiola, Tratado de Nobleza, h. 114 r.-116 vto.; MoReno, Discvrsos de la Nobleza, h. 68 r.-69 r.

175 Debía ser «de grand linaje, e muy leal: e entendido, e sabidor». Alfonso X, Las Siete Partidas, vol. I, fol. 26 vto. Ver Guardiola, Tratado de Nobleza, h. 120 vto.-121 vto.; Moreno, Discvrsos de la Nobleza, h. 71 r.-vto.

176 «De los Condes se deriuan los Vizcondes que son inferiores a la dignidad de Condes. Porque Vizcondes, que agora dezimos, quitada la C. primera, y la E. mudada en z. Vizconde, quiere dezir persona puesta en lugar de Conde, o que espera sus vezes: y assi en Francia se vsa mucho este nombre de dignidad: la qual gozauan los primogenitos de los Condes, como mayorazgos que esperauan las vezez paternas, y en sus ausencias eran los que sus vezez tenian, a los quales solos apartaua cierta porcion del estado paterno, para que gozassen hasta que todo viniessen a heredar». GuARDIOLA, Tratado de Nobleza, h. 116 vto.-117 r. Ver Moreno, Discvrsos de la Nobleza, h. 69 r.

177 Ver Guardiola, Tratado de Nobleza, h. 119 r.-vto.; Moreno, Discvrsos de la Nobleza, h. 71 r.-vto.; Salazar, Origen de las dignidades, fol. 132 r.-133 r. 


\section{(h. 158) Cómo prefieren los unos ilustres a los otros}

Supuesto que hay mayor y menor en las dignidades, está claro que la menor ha de acatar a la mayor. El duque prefiere al marqués, el marqués al conde, el conde al adelantado, el adelantado al vizconde. Casaneo en el Catalogus Glorice Mundi trae muchos autores de esta opinión y todos afirman que aunque sea creada nuevamente una dignidad de las mayores ha de preferir a la antigua menor, pero esto no se entiende en los hijos de los reyes o príncipes absolutos, que estos por la excelencia de su sangre deben ser preferidos. Algunos dicen que a los duques siguen los adelantados, pero la costumbre está en contrario. Los condestables, almirantes, duques, marqueses y condes pueden traer coroneles ${ }^{178}$ sobre sus armas y poner sitiales $^{179}$.

\section{De traer los nobles armas y su antigüedad, y quién tiene potestad de darlas y para qué efecto}

/ Las divisas y señales de las armas de los nobles nacieron de los triunfos de vencimiento y victorias que tuvieron. Casaneo en las consideraciones 21 y 22 de la primera parte del Catalogus Glorice Mundi dice que es grande la antigüedad de traerlas ${ }^{180}$ y compruébalo con que la reina Semiramis, mujer del rey Nino, primer monarca y fundador de Nínive, que reinó a los 2058 años antes del nacimiento de nuestro redentor Jesucristo, traía una paloma por insignia, y la tribu de Judá un león ${ }^{181}$, y la ley XVI de la Segunda Partida título XIX dice que griegos y romanos hicieron divisas en las guerras ${ }^{182}$ y el emperador Carlomagno hizo teñir las banderas y estandartes y ordenó cómo se habían de llevar, declarando sus títulos y preeminencias ${ }^{183}$. Al principio pintaba cada uno en su escudo las armas conforme a la

178 Hay que señalar que «la Corona Real es ancha, y grande, y que tiene las puntas floreteadas en señal de suprema jurisdicion, y señorio, y el Coronel es corona pequeña, que tiene las puntas llanas, delgadas, y pequeñas». Moreno, Discvrsos de la Nobleza, h. 105 r.

179 «El assiento, o silla con un pequeño banco delante, cubierto de un tapéte con una almohada, ò coxin encima, y otra à los pies de la silla, de que usan los Reyes, Principes, y Prelados en la assistencia de las funciones públicas». Diccionario de la lengua castellana... tomo sexto, que contiene las letras S. T. V. X. Y. Z, En Madrid, en la imprenta de la Real Academia Española, por los Herederos de Francisco de el Hierro, 1739, 122.

180 Cassanaeus, Catalogus, fol. 12 r.-vto.

181 Sobre las insignias de las doce tribus de Israel ver MoRENo, Discvrsos de la Nobleza, h. 96 vto.-97 r.

182 No es correcta la cita. «Señales conoscidas pusieron antiguamente que traxessen los grandes omes en sus fechos, e mayormente en los de guerra». Alfonso X, Las Siete Partidas, vol. I, Segunda Partida, título XXIII, ley XII, fol. 86 r. Ver también las leyes XIII, XIV y XV. Deseamos subrayar que es inexacta la referencia de Melio, máxime cuando el título XIX sólo tiene nueve leyes.

183 Carlomagno adoptó el águila como señal. 
hazaña que hacía, y hasta que la hiciese lo traía en blanco. Después las dieron los reyes y ninguno usaba de armas sin facultad real, y Bartolo en el Tratado de insignes dice que negársele la potencia de dárselas sería sacrilegio ${ }^{184}$.

(h. 159) El fin para que se usó de ellas fue para conocerse en las batallas y que el príncipe o caudillo, viendo al caballero cobarde y que hacía vileza, le denostase o avergonzase, y también para que haciendo hechos valerosos fuesen notorios, y el que los traía con aquel honor se alentase a más. David, salmo 77, dice que pusieron en sus escudos armas y banderas por señales ciertas de sus victorias ${ }^{185}$, y Eusebio, libro IX de su Historia Eclesiástica, que al emperador Constantino Magno para pelear con Majencio cuando le venció le fue dada milagrosamente del cielo por divisa la señal de la cruz santa y alrededor de ella escritas estas palabras: con esta señal vencerás ${ }^{186}$. La cual es la cruz y hábito de caballería y orden militar del título de San Jorge llamada Angélica de la casa Constantiniana e Imperio Griego, y la

${ }^{184}$ Son los reyes quienes pueden y deben conceder las armas «a quienes quisieren, y como fuere su voluntad: como lo resuelue Bartulo, el qual dize, que a el le dio el Emperador Carlos Quarto, que pudiesse traer por armas vn Leon roxo con dos colas en campo de oro. Son pues de tanta autoridad las armas que los Reyes conceden, que por el mismo caso que las den a vn plebeyo, es visto darle tambien la nobleza que para traerlas se requiere: porque todo aquello que el Rey quisiere lo podra hazer, y es sacrilegio dudar de su poder». Moreno, Discvrsos de la Nobleza, h. 102 r.-vto. Ver BARTOLO DE SASSOFERRATO (1314-1357), Tractatus de insigniis et armis, en Consilia cum additionibus Bernardini Landriani. Quaestiones. Tractatus, Lugduni, Johannes Siber, h. 1495, fol. 119 r. Melio traduce literalmente sus palabras, pero cambiando potestad por potencia. Estamos ante uno de los juristas más influyentes y difundidos de todos los tiempos. En 1356 publicó este tratado, una de sus obras más importantes, y que es el primer registro de insignias y armas europeas. Con él da inicio la historia de los escudos de armas y blasones. Sobre la presencia de manuscritos con sus obras en España ver GARCíA y GARCíA, Antonio, «Bartolo de Saxoferrato y España», Anuario de Estudios Medievales, 9 (197479), 439-67.

${ }^{185}$ El pasaje bíblico que más se asemeja es el siguiente: «Hiciste ver a tu pueblo cosas duras, nos diste a beber el vino del vértigo. Pero has dado bandera a los que te temen para que se recojan ante el arco». Salmos, 60, 5-6. En la Biblia se menciona que Dios instó a Moisés a que cada tribu de Israel tuviera sus banderas y señales: «Habló Yavé a Moisés, diciendo: «Que acampen los hijos de Israel cada uno junto a su enseña, bajo las enseñas de sus linajes, frente al tabernáculo de reunión y en torno de él».» Números 2, 1-2. Esta cita de Melio y la que encontramos al principio de San Agustín la dificultad que presentan para ubicar su procedencia exacta radica en que deben tratarse de versiones un tanto libres de la frase original.

186 «Pero él, que poseía la piedad para con Dios como algo innato, sin perturbarse lo más mínimo por las aclamaciones ni engreírse con las alabanzas, muy consciente de que la ayuda provenía de Dios, ordena inmediatamente que en la mano de su propia estatua se coloque el trofeo de la pasión salvadora, y al ver que le erigían en el lugar más público de Roma sosteniendo en su mano derecha el signo salvador, les urge a que graben esta inscripción en lengua latina con sus mismas palabras: «Con este signo salvador, que es la verdadera prueba del valor, salvé y libré a vuestra ciudad del yugo del tirano; más aún, la libré y restablecí al senado y al pueblo romanos en su antiguo renombre y esplendor». Eusebio de CESAREA (h. 260-339), Historia Eclesiástica 2 ed., Texto, versión española, introducción y notas por Argimiro Velasco-Delgado (O.P.), Madrid 1997, vol. II, lib. IX, 10-11, 577-78. 
primera con que los cristianos honraron sus pechos desde el tiempo del referido emperador Constantino, hijo de la reina Santa Elena, que transfirió la silla del Imperio de Roma a Grecia, la cual se instituyó debajo / de la regla de San Basilio, y hoy con la ruina y pérdida del Imperio Griego está ya casi deshecha ${ }^{187}$.

\section{De la significación de las armas}

Los animales feroces denotan vencimiento o hechos hazañosos ${ }^{188}$. Los castillos, torres, puentes, almenas, ríos, muros, sierras y peñas, haberlos ganado o defendido. Las escalas, asaltos o subidas peligrosas. Antenas, velas, remos, naves, fustas y áncoras, victorias de mar. Los armiños ${ }^{189}$ limpieza, veros ${ }^{190}$ verdad. Cruces y aspas fe ${ }^{191}$. Los bastones ser de la casa real de Aragón o Condes de Barcelona, o haber quebrantado alguna empalizada. Las flores de lis ser de la casa real de Francia, o haberles ganado en batalla o desafío. Las cadenas ser de la casa real de Navarra, o haber quebrantado el cerco que puso el rey Miramamolín ${ }^{192}$. Las bandas o fajas algún hecho o acometimiento heroico ${ }^{193}$. El águila gran valor. Las barras victoria. Hay otras muchas maneras de armas que tienen diversas (h. 160) significaciones, por haberlo sido las ocasiones y trances en que se ganaron. Ninguno puede traer las armas reales de la manera que las trae el rey en cuarteles, y hay ley del reino que lo prohíbe. Se tuvo atención al elegir las armas de pintarlas según sus naturalezas: a los animales feroces en su ferocidad, los ligeros en su ligereza, los domésticos en su domesticidad, los estables en su estabilidad. Ha de estar cualquier animal la cara al lado derecho, el león rampante, el caballo corrien-

${ }^{187}$ La Sagrada Orden Militar Constantiniana de San Jorge tiene su origen en la Caballería Aurata Constantiniana, creada por Constantino tras la victoria sobre Majencio $(† 312)$ con cincuenta hombres a los que armó caballeros. El término aurata hace referencia al collar de oro que llevaban sus dignatarios. El signo de la cruz se grabó en los estandartes y armaduras. Las primeras reglas del Obispo San Basilio (329-379) fueron aprobadas el año 456 por el Papa San León I Magno (400-461).

188 «Los Leones significan braueza, y valentia: las Aguilas, valentia con presteza, y ligereza: los lobos, valentias y vencimientos con pressa y despojos». Moreno, Discvrsos de la Nobleza, h. 93 r.

189 «Los armiños son unas manchas de sable en forma de pequeños triángulos o colitas que se colocan en campo de argent». RiQueR, Martín de, Manval de Heráldica Española, Barcelona 1942, 8.

190 «Los veros son una especie de vasos o campanillas de argent y de azur que encajan perfectamente, invertidos, unos con otros; cuando son de otros esmaltes, por ejemplo, de oro y de gules, se llaman verados». RiQuer, Manval de Heráldica, 7.

191 «Las Aspas que muchos Caualleros, è hijosdalgo traen en sus escudos de armas, tuuieron principio de aquella batalla que ganaron de los Moros que estauan sobre Baeça dia de san Andres, lleuando por su Capitan general a don Lope Diaz de Haro, en tiempo del Rey don Fernando el Tercero». Moreno, Discvrsos de la Nobleza, h. 90 vto.

${ }^{192}$ Se refiere a la batalla de las Navas de Tolosa (1212). Ver ídem, h. 89 vto.-90 r.

${ }^{193}$ Las bandas «representan postura, ò arrimo de vanco pinjado, ò cosa que a esto parezca: faja, ò barra representa vitoria de batalla, o de trance entre vn Caballero, y otro». Ídem, h. 92 vto. 
te, la onza saltante ${ }^{194}$, el lobo cazando, el oso levantado sobre los pies, el águila volante, rapante, y lo mismo las demás aves de su calidad. La paloma y las demás aves de su calidad y naturaleza andantes, benignas y mansas. El castillo torreado, la torre firme y derecha, el muro fuerte. De manera que todas las cosas estén según su propiedad y naturaleza.

\section{Que los plebeyos no pueden usar de armas, y si será lícito a un noble traer las de otro, y por qué causas se pierden y lo que el noble debe saber}

/ A los plebeyos no es permitido traer armas e insignias como a los nobles, y si lo hacen cometen delito, y les pueden ser raídas como lo refieren Casaneo y otros. Porque cosa ridícula sería ver a los innobles por este medio hurtar la fama y hechos de aquellos de quien no proceden, y la gloria adquirida por valor y virtud no puede ser dada al que no la mereció. El otro punto, si siendo dos nobles puede traer el uno las armas del otro que no es de su linaje sobre que hay diversas opiniones, algunos dicen que no se pueden traer, sino por deudo de consanguinidad, autoridad de príncipe, o tiempo, o habiéndolas ganado en el campo, o habiéndolas perdido el que las usaba por caso aleve, pero algunos linajes hay hoy que siendo diferentes en sangre o apellido traen unas mismas armas ${ }^{195}$, como son los de Sandoval y los Carvajales, que en campo de oro traen banda negra, los Vargas y Mariños, ondas azules en campo blanco, y los Argotes y Quintanillas, cruces veradas ${ }^{196}$. Lo que al noble conviene saber (h. 161) es la definición de su nombre, la antigüedad de su linaje, su naturaleza, sus armas, las de su rey, las de su provincia y patria, y el alto honor de la caballería ${ }^{197}$, conforme los capítulos de este tratado, el cual da fin.

194 «Mamífero carnicero de tamaño mayor que un perro y parecido a él». CADENAS Y VICENT, Vicente de, Diccionario Heráldico. Términos, piezas y figuras usadas en la ciencia del blasón 6 ed., Madrid 2002, 130. Saltante es sinónimo de la posición de rampante. Ver ídem, p. 151 y figura 521 (p. 281).

195 Esto se debe a que «en quanto al linage son vnos, y proceden de vn tronco, y tienen vn mismo origen: y por auer los vnos ganado nueuos solares de diferentes nombres, se diferenciaron en los apellidos». MoReno, Discvrsos de la Nobleza, h. 100 r.

196 Es decir, una cruz de veros. Ver nota 190.

197 «Finalmente es bien, que aduiertan los nobles tienen obligacion de saber lo necessario para la buena traça, y pintura de sus armas, y deuen saber hazer buena relacion dellas, y de sus linajes: y estan obligados a conocer las insignias, y armas de su Rey, y de su patria, pues ignorarlo seria gran torpeza: y cierto es mayor la de los que se glorian mucho de sus armas, sin atender a lo que por ellas estan obligados a obrar, siguiendo la virtud, y imitando el valor de los que primeramente las ganaron, que es el fin, y efecto para que se introduxeron». Moreno, Discvrsos de la Nobleza, h. 120 r. 